\title{
Extension, hyperextension and mantle exhumation offshore Norway: a discussion based on 6 crustal transects
}

\author{
Per Terje Osmundsen 1,2,3, Gwenn Péron-Pinvidic' ${ }^{1}$ Jörg Ebbing ${ }^{4}$, Duncan Erratt ${ }^{5}$, \\ Erik Fjellanger ${ }^{6}$, Dag Bergslien ${ }^{6} \&$ Svein Erik Syvertsen ${ }^{6}$
}

${ }^{1}$ Geological Survey of Norway, Post Box 6315 Sluppen, N-7491 Trondheim, Norway.

${ }^{2}$ Department of Arctic Geology, University Centre in Svalbard, N-9171 Longyearbyen, Norway.

${ }^{3}$ Institute for Geosciences, University of Oslo, P.O. Box 1047, N-0316 Oslo.

${ }^{4}$ Institute of Geosciences, Kiel University, 24118 Kiel, Germany.

${ }^{5}$ ExxonMobil International Limited, Leatherhead, U.K.

${ }^{6}$ ExxonMobil Production and Exploration Norway AS, Grenseveien 6, N-4313 Sandnes, Norway.

E-mail corresponding author (Per Terje Osmundsen): per.osmundsen@ngu.no

\begin{abstract}
In spite of its classification as 'magmatic', the rifted margin off Mid Norway evolved as a hyperextended margin in Late Jurassic and Cretaceous time, with a pre-breakup structural evolution that resembles that of magma-poor margins. Because the distal margin was not drilled to crystalline basement, considerable uncertainty exists with respect to the distribution of lithologies at depth. In this contribution, we discuss the implications of various scenarios for deep-seated lithologies and evaluate the possibilities for mantle exhumation in the deep margin offshore Norway. A suite of JurassicCretaceous, very large-magnitude, extensional faults that exhumed successively deeper structural levels seawards are well imaged in recent long-offset seismic reflection data. Based on these key profiles, we document the structural configuration that created the extremely sharply tapered south Møre margin as well as subhorizontal detachment faults in the distal Vøring margin. The latter were associated with rotated extensional allochthon and supradetachment basins and contributed to the exhumation of very deep levels including rocks from the lower crust and/or upper mantle. In the outer margin, truncation and excision of this system by a new set of incising detachment faults occurred later in the Cretaceous and the earliest Cenozoic. We discuss the relationships between these detachment systems under the distal and outer margins and positive structural features such as the Rån and Gjallar ridges. The interpretation of basement lithologies at depth in the distal margin is ambiguous due to overlap in physical properties. Based on a process-oriented evaluation of the different interpretation scenarios, we favour a model where mantle windows were exhumed in the footwalls of some of the master faults in the Cretaceous.
\end{abstract}

Keywords: Rifted margins, Mid Norway, depth-converted transects, hyperextension

Received 21. January 2016 / Accepted 28. November 2016 / Published online 15. March 2017

\section{Introduction}

The Mid Norway rifted margin (Figs. 1, 2) evolved through several rift phases, climaxing in Permo-Triassic, Late Jurassic-Early Cretaceous and Late CretaceousPalaeogene time (e.g., Blystad et al., 1995; Brekke, 2000). The Trøndelag Platform, considered to constitute the margin's proximal domain (Péron-Pinvidic et al., 2013), preserves wedge-shaped successions of rotated strata beneath more gently dipping strata of Late Triassic and younger age. The regional unconformity that caps Jurassic and older basin strata in the Trøndelag Platform, Halten Terrace and Slørebotn subbasin areas is proven in a large number of exploration wells and is normally referred to as the base of the Cretaceous (BCU; Blystad et al., 1995; Brekke, 2000). The Late Jurassic-Early Cretaceous rift phase(s) was the most important with respect to crustal thinning, and associated with large-magnitude normal faults that cut and displaced the stratigraphy

Osmundsen, P.T., Péron-Pinvidic, G., Ebbing, J., Erratt, D., Fjellanger, E., Bergslien, D. \& Syvertsen, S.E. 2016: Extension, hyperextension and mantle exhumation offshore Norway: a discussion based on 6 crustal transects. Norwegian Journal of Geology 96, 343-372. http://dx.doi.org/10.17850/njg96-4-05. 
of the platform and terraces and paved the way for the deep Cretaceous Møre and Vøring basins (e.g., Blystad et al., 1995; Faleide et al., 2008). The large thicknesses of Cretaceous strata, as well as refraction-based models of the crystalline crust in the Møre and Vøring basins, indicate that crustal thickness was dramatically reduced over substantial areas outboard of the platforms and terraces (e.g., Brekke, 2000; Mjelde et al., 2005, 2009a, b; Faleide et al., 2008; Breivik et al., 2011; Kvarven et al., 2014).
There has been some controversy over whether this evolution should be viewed as one combined event or separated into distinct Late Jurassic and Early Cretaceous events (Lundin \& Doré, 1997; Doré et al., 1999; Faleide et al.,2008). The problem is not easily resolved due to the lack of well control in the deep basins. It is well known, however, that faulting in the outer margin is Late Cretaceous into Paleogene in age (e.g., Ren et al., 1998; Fjellanger et al., 2005), and a basinward migration of rifting activity has been argued for by several workers (e.g., Lundin \& Doré,

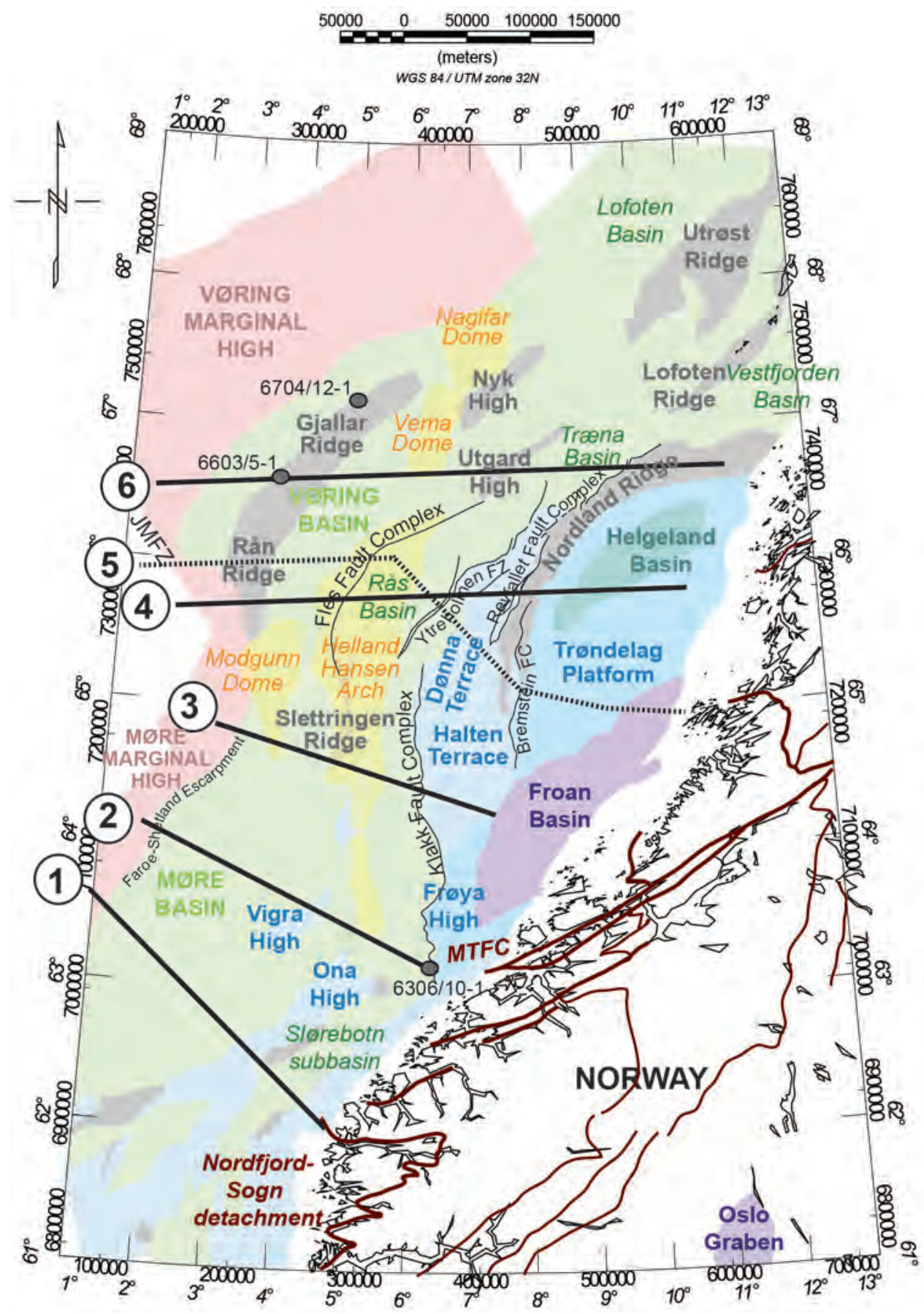

Figure 1. Map of the Mid Norway rifted margin showing main structural elements (simplified from Blystad et al., 1995) and locations of geoseismic transects used in this study. Colours: green - Cretaceous basins, blue - platform and terrace areas, grey - Cretaceous highs, pinkmarginal highs, violet - Permian-Triassic basins. Abbreviations: MTFC - Møre-Trøndelag Fault Complex; JMFZ - Jan Mayen Fracture Zone. 
1997; Osmundsen \& Ebbing, 2008; Péron-Pinvidic et al., 2013). Basinward migration of rifting activity has been well documented in the hyperextended Iberian margin (e.g., Péron-Pinvidic et al., 2007; Sutra et al., 2013). Such an interpretation has consequences for the interpretation of deep-seated unconformities in distal margins.

A deep-seated, regional unconformity observed under thick Cretaceous deposits in the deep Møre and Vøring basins is undrilled and cannot be directly correlated with that of the platform and terrace areas. This unconformity has, nevertheless, been interpreted to represent the BCU by many workers (e.g., Brekke, 2000; Osmundsen et al., 2002). A seaward-migrating faulting activity, such as discussed by Lundin \& Doré (1997), would, however, lead to a seaward younging of this unconformity, and to an increasing potential for preservation of Cretaceous strata in the down-faulted half-graben. More distal parts of the Møre and Vøring basins were poorly imaged, with flatlying strata to great depths and dense networks of sill intrusions in some areas. In the better imaged parts of the outer margin, a marked onlap unconformity rises northwestwards out of the poorly imaged levels of the basins, and was interpreted by some early workers to represent the BCU (e.g., Swiciecki et al., 1998). Exploration wells drilled in the outer ridges areas (e.g., 6704/12-1 and 6603/5-1) have demonstrated a (Mid-Late) Cretaceous age for this unconformity and synrift deposits as young as the Maastrichtian (e.g., Fjellanger et al., 2005; http://www. npd.no/). Moreover, Jurassic rocks were not encountered below the unconformity in any of the wells. Thick successions of densely faulted Cretaceous rocks occupy several kilometres of stratigraphic section below the base of the Cenozoic in the outer margin (e.g., Brekke, 2000; Fjellanger et al., 2005). Thus, the basin architecture of the outer margin differs from that of the more proximal areas, to an extent that is not yet well constrained.

Eocene breakup was associated with voluminous magmatism, as manifested by seaward-dipping reflectors, lava flows and hyaloclastic deltas (e.g., Planke et al., 2000, 2005; Berndt et al., 2001). A high-velocity, lower-crustal body that occurs under the outer margin was interpreted by a number of workers as a magmatic underplate (e.g., Skogseid et al., 1992; Mjelde et al., 2009b), albeit other interpretations are possible (e.g., Lundin \& Doré, 2011).

The combination of highly extended crust with largemagnitude extensional detachment faulting led some authors to suggest that the rifted margin offshore Norway shared a number of characteristics with the Iberian margin, and that the margin underwent a phase of hyperextension prior to magmatic breakup (Ren et al., 1998; Osmundsen \& Ebbing, 2008; Lundin \& Doré, 2011; Péron-Pinvidic et al., 2012, 2013). Another common observation appears to be the evolution of margin deformation through a basinward migration of rifting (Lundin \& Doré, 1997; Péron-Pinvidic et al., 2007;
Ranero \& Pérez-Gussinyé, 2010; Sutra et al., 2013). Since the dredging of serpentinised mantle rocks at the Iberian margin (Boillot et al., 1980) and their subsequent drilling by several ODP Legs (Shipboard Scientific Party, 1987a, b, 1994, 2004), pertinent questions at deep margins relate to the degree of crustal thinning and to whether mantle was exhumed to the seafloor during large-magnitude extension (Whitmarsh et al., 2001; Manatschal et al., 2007; Péron-Pinvidic \& Manatschal, 2009; Lundin \& Doré, 2011; Péron-Pinvidic et al., 2013). Since the geophysical properties of continental crystalline crust and serpentinised subcontinental mantle overlap considerably, this question cannot be answered easily for margins that were not drilled to crystalline basement. Thus, one of the benchmarks of hyperextension identified in the Iberia-Newfoundland system, the exhumation of serpentinised mantle to the seafloor (Boillot et al., 1980; Manatschal et al., 2001; Whitmarsh et al., 2001), cannot be proven directly offshore Norway. Several workers have, however, discussed the possibility, and some have suggested that it may have occurred, based on interpretation of seismic reflection data, refraction data, potential field data and modelling (Ren et al., 1998; Osmundsen \& Ebbing, 2008; Lundin \& Doré, 2011; Reynisson et al., 2011; Péron-Pinvidic et al., 2012, 2013; Rüpke et al., 2013). Others reject this possibility (e.g., Nirrengarten et al., 2014), or propose alternative solutions that involve bodies of dense, eclogite-facies, continental crust under the most highly thinned areas (Gernigon et al., 2004; Mjelde et al., 2012).

Ren et al. (1998) were the first to suggest the presence of shallow serpentinised mantle under extensional detachments in the Gjallar Ridge and compared the Vøring margin to that offshore Iberia. Further evidence for hyperextension offshore Norway was based largely on interpretation of lines from long-offset seismic reflection data, shot and recorded to 12 and 14 seconds twoway time (s twt) in the mid-1990s. Largely, arguments were based on the interpretation of large-magnitude extensional faults in what is now known as the necking domain as well as in the inner parts of the distal margin (Osmundsen \& Ebbing, 2008; Péron-Pinvidic et al., 2013). This area coincides with areas where seismic refraction studies and potential field modelling (Faleide et al., 2008; Mjelde et al., 2009a, b) suggested a very dramatic reduction of the crystalline crust.

In the last decade, long-offset seismic reflection profiles have been acquired over large parts of the Norwegian margin, with recorded depths of 10 and $12 \mathrm{~s}$ twt. More recently acquired refraction data (Breivik et al., 2011; Kvarven et al., 2014) and potential field-based crustal models provide additional constraints (e.g., Ebbing et al., 2006; Ebbing \& Olesen, 2010). Recent works on hyperextended margins elsewhere have presented a number of concepts that should be considered when discussing the Norwegian margin (e.g., Blaich et al., 


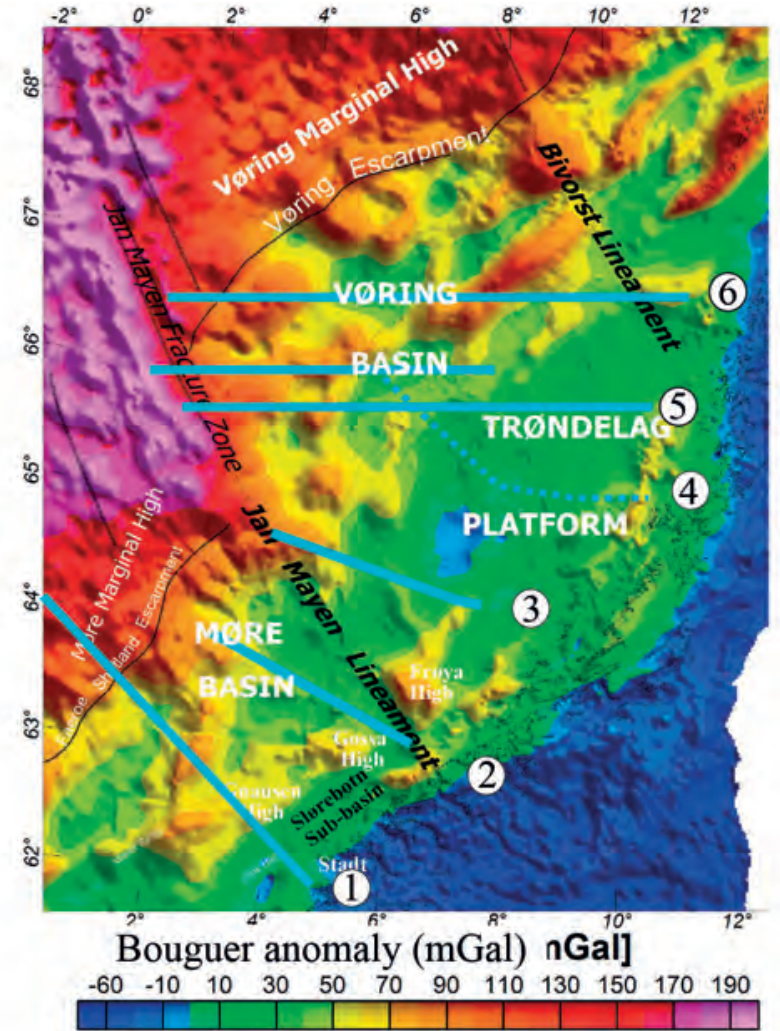

A

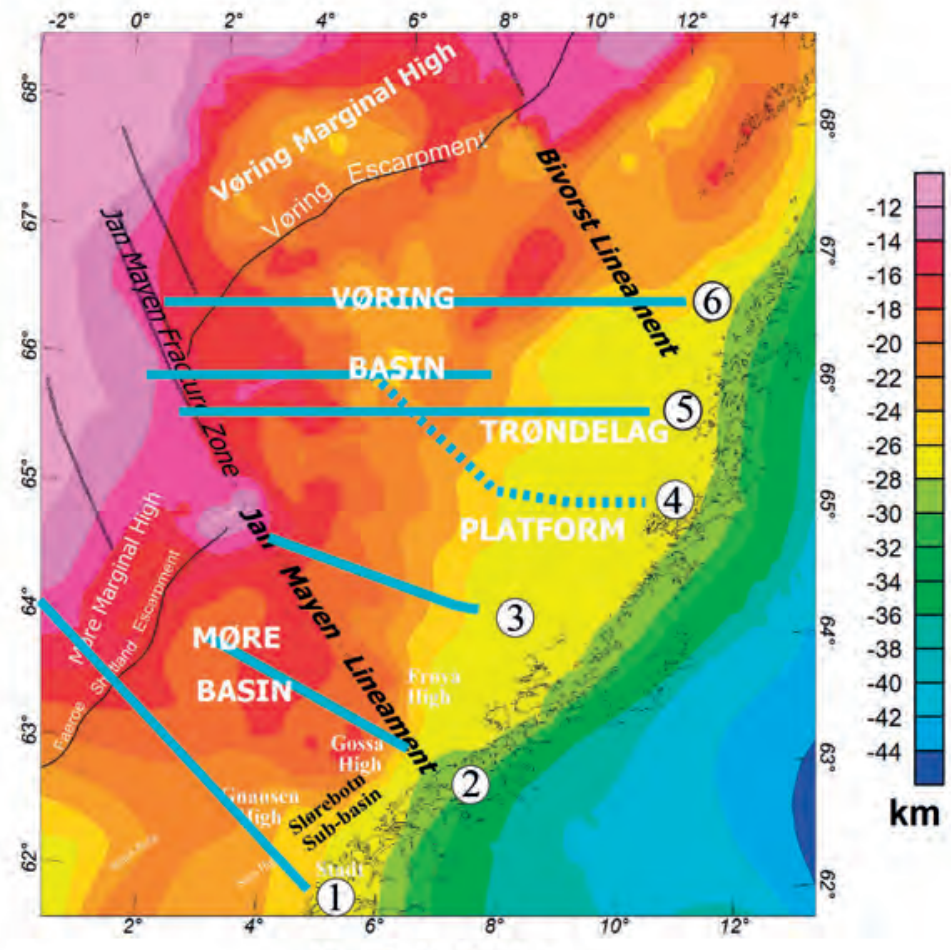

C

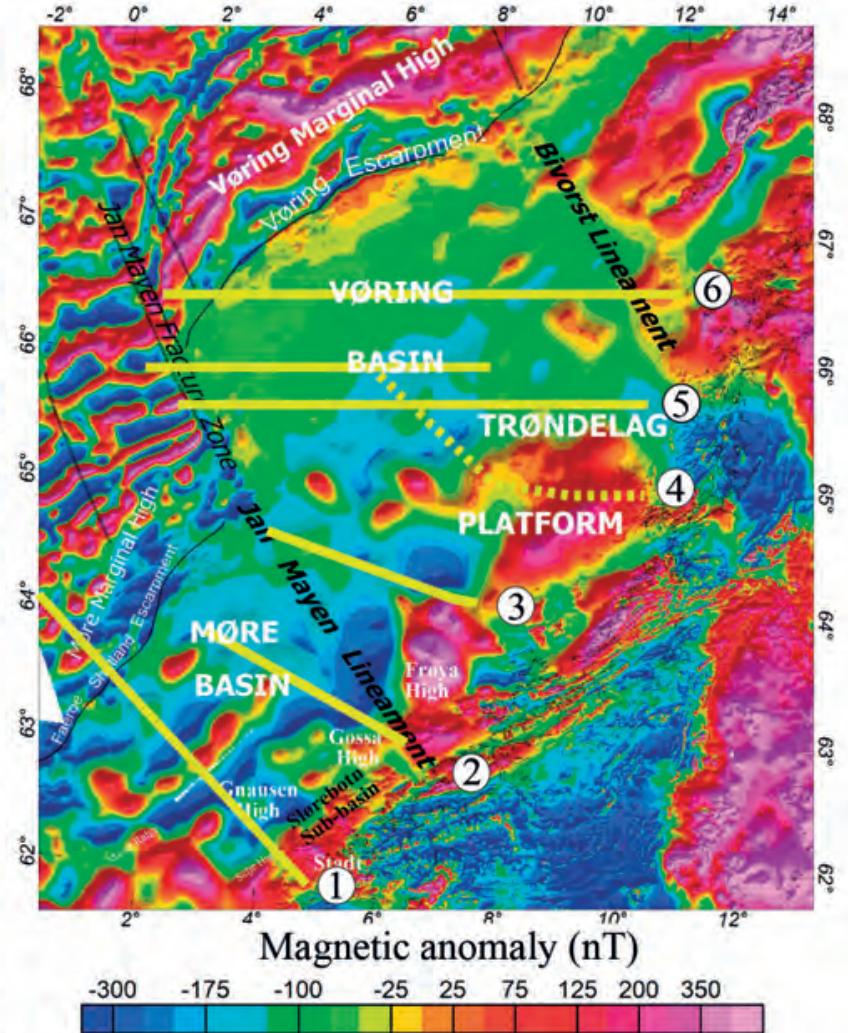

B 
2011; Franke, 2012; Péron-Pinvidic et al., 2013; Savva et al., 2014; Stica et al., 2014; Tugend et al., 2014). In particular, this relates to the succession of rifting modes and principal structures, the mechanisms behind largemagnitude crustal thinning, the nature of the continentocean transition and the possibility for altered mantle to constitute parts of the basement in the deep margin.

Below, we describe and discuss four, new, geoseismic transects through the Mid Norway rifted margin, along with slightly revised interpretations of two previously published transects (Transects 1 to 6, Figs. 3-9). We discuss the crustal structure along these transects based on interpretation of the long-offset seismic reflection data, published refraction profiles and potential field modelling. We present structural scenarios for the extremely sharp crustal neck in the southern Møre area, recently remodelled based on new seismic refraction data (Kvarven et al., 2014). Furthermore, we provide novel interpretations of parts of the distal margin, discuss the significance of the so-called ' $\mathrm{T}$ '-reflector and the general ambiguity of interpretation at distal rifted margins that were not drilled to basement.

\section{Seismic and potential field data}

\section{Seismic reflection data}

Our geoseismic transects are based on the interpretation of the seismic reflection profiles GMNR94-102, MNR05-7300, MNR05-7332 and MNR05-7397. For a more comprehensive overview we also include modified versions of our previously published interpretations of GMNR94-103 and GMNR94-104. The data quality ranges from fair to excellent, depending on depth and on location in the margin. For instance, both surveys provide very high-quality imaging of structures in the proximal, necking and inner distal domain, but the MNR05-lines provide the best images from the outer parts of the distal margin. On the other hand, the deeper recording of the GMNR94 data (14 s twt) provides additional information from the deep crust or upper mantle that cannot be obtained from the $10 \mathrm{~s}$ MNR05 data. The GMNR survey also gives a convenient regional framework for deeper interpretations. For correlation purposes we have use a mixed grid of long-offset and conventional seismic data of variable quality including lines recorded to 7, 10 and $12 \mathrm{~s}$ twt acquired between 1984 and 2002.

Depth conversion of the profiles that form the basis of our geoseismic transects was performed using check shot information, velocity data from wells in the platform, terrace and subbasin areas, published regional velocity models from OBS experiments (Raum et al., 2002; Mjelde et al., 2009a, b; Breivik et al., 2011; Kvarven et al., 2014), and 2D and 3D potential field modelling. We have used the Easydepth ${ }^{\circ}$ tool from Franlab-Beceip for interpretation and depth conversion of single seismic transects, Petrel $^{\circledR}$ seismic mapping software (Schlumberger) for correlation purposes, and IGMAS (Interactive Geophysical Modeling ASsistant) for combined gravity and magnetic modelling.

\section{Gravity and magnetic data}

The gravity compilation used to calibrate the geoseimic transects in this contribution was based on $c .59,000 \mathrm{~km}$ of marine gravity profiles collected by the Norwegian Petroleum Directorate, the Norwegian Mapping Authorities and the oil industry, in addition to gravity data from satellite altimetry in the deep-water areas (Olesen et al., 2010b).

Fig. 2A shows the resulting Bouguer anomaly map using a correction density of $2200 \mathrm{~kg} / \mathrm{m}^{3}$. The magnetic anomaly map is shown in Fig. 2B based on a wealth of aeromagnetic surveys acquired during the last 50 years. Most of the study area is covered with flight lines with a spacing of $2-5 \mathrm{~km}$ (see Olesen et al., 2010a, b for a detailed review of the surveys).

Both the gravity and the magnetic anomaly maps show clear differences between the proximal margin domain (the Trøndelag Platform), where the top basement appears to vary locally in depth, and the outer domain (the Vøring Basin), where top basement is generally very deep.

\section{D potential-field based crustal model}

The Moho under the deep Møre and Vøring basins is generally not well imaged by seismic reflection data. To constrain the crustal thickness along the seismic reflection profiles used in this study, we have used existing 3D geophysical models of the Mid-Norwegian margin as a basis (e.g., Ebbing et al., 2006, 2009; Reynisson et al., 2011 Kvarven et al., 2014). We have employed the gravity and magnetic data described above and the IGMAS, which calculates the potential field effect of a crustal model by triangulation between modelling planes (Götze \& Lahmeyer, 1988), to expand and refine the 3D models used in previous works (see Ebbing et al., 2006; Osmundsen \& Ebbing, 2008; Reynisson et al., 2011 for details). The most important parameters in the construction of the $3 \mathrm{D}$ model are the crustal geometry and petrophysical properties (density, magnetic susceptibility and Q-ratio) for the crust and upper mantle. Fig. $2 \mathrm{C}$ shows the depth to Moho from the 3D model (after Ebbing \& Olesen, 2010). The deep structure of the Møre margin has been updated using the results of three modelled OBS profiles by Kvarven et al. (2014). For a more detailed discussion on velocity, density and magnetic parameters, see Ebbing et al. $(2006,2009)$ and Kvarven et al. (2014). The modelled parameters for the different stratigraphic units and crystalline crustal types (Table 2) were based on data obtained from basement 
rocks onshore and drilled sedimentary units in the offshore platform and terrace areas. For the distal margin, we consider also other possibilities for the translation of physical parameters into lithological units, as discussed below.

For the present study, we loaded depth-converted seismic interpretations into the $3 \mathrm{D}$ model. The $3 \mathrm{D}$ geometry was then used first to evaluate the interpretation. In case of large differences between seismic interpretation and 3D model geometry, the geometry was adjusted by forward modelling. The depth-converted seismic interpretations were then combined with the resultant 3D model to discuss the distribution of lithological units at depth and to construct the final geoseismic sections.

\section{The construction of geoseismic transects}

Below, we present six, depth-converted, geoseismic transects through the Mid-Norwegian margin. Construction of the transects was carried out using an interactive approach that started with seismic interpretation in two-way time (twt). Following this, the velocity models required for depth conversion were constructed with the aid of published seismic refraction profiles and well data. Upon depth conversion, potential field modelling was carried out (see section 2) to better constrain the lower parts of the geoseismic transects. Several iterations of modelling and interpretation were performed for each section, to optimise the correlation between the different datasets and to arrive at wellconstrained and geologically realistic transects. The seismic reflection profiles used to construct the transects were the GMNR94-102 and GMNR94-103 from the Møre Basin and GMNR94-104, MNR05-7300, GMNR94-105, MNR05-7332 and MNR05-7397 from the Vøring Basin (see Fig. 1 for locations).

Each transect is systematically described below in terms of basement structure and basin configuration. For most of the transects, more than one scenario was possible due to the overlap between geophysical parameters of different rock units or because of uncertainties in the interpretation of the seismic reflection data (see discussion). We present a number of different scenarios for each transect and discuss their geological significance. We also discuss what we perceive as principal problems in the correlation of seismic reflection data with refraction and potential field data.

\section{Transect 1: South Møre Basin}

Transect 1 was constructed to reveal the deep structure of the south Møre basin (Fig. 3). It corresponds to our interpretation of two regional profiles: the GMNR94$102 \mathrm{~A}$ and the GMNR94-102 R. The seismic section GMNR94-102 A was recorded to $12 \mathrm{~s}$ twt and is of very good quality. However, reflectivity is less well defined below $c$. $7 \mathrm{~s}$ twt in its northwestern parts. GMNR94-102 $\mathrm{R}$ is of fair to very good quality and was recorded to $14 \mathrm{~s}$ twt. The resolution of the top of basement is poor and in the northwestern part of the section, reflectivity at depth is hampered by intrusions and overlying extrusive rocks.

\section{Basement structure}

In the southeastern parts of the section, between profile $\mathrm{km} \mathrm{c.} 120$ and 30, the crystalline crust tapers sharply off, bound by the northwest-dipping top of crystalline basement and the Moho, which rises steeply from a depth in excess of $30 \mathrm{~km}$ close to the southeast end of the section to $c .18-20 \mathrm{kms}$ depth at profile $\mathrm{km} c .40$ (Fig. 3).

Figure 3. Transect 1. (A) Two-way time interpretation based on long-offset seismic reflection profiles GMNR94-102A and GMNR94-102R. Note deep reflector band rising from the base of the southeastern parts of the section (DRB), the large normal fault $F_{1}$ interpreted to incise into DRB and the inferred fault $F_{2}$, likely to represent a large-magnitude detachment fault at the toe of the most sharply tapered crustal wedge. (B) shows the seismic reflection profile GMNR94-102A from the southeastern half of the transect. Note seismic expression of the DRB and the well-defined $F_{1}$ and adjacent sedimentary basin. (C) Crustal-scale density model extracted from the potential field-based $3 D$ model along the trace of transect 1 . (D-F) shows alternative interpretation scenarios for transect 1 , based on the above interpretation calibrated with the $3 D$ crustal model anchored in Kvarven et al. (2014). In all sections, bodies with density $3300 \mathrm{~kg} / \mathrm{m}^{3}$ are considered to represent mantle rocks. In (D), bodies with densities less than $3300 \mathrm{~kg} / \mathrm{m}^{3}$ but larger than $2700 \mathrm{~kg} /$ $\mathrm{m}^{3}$ are considered to represent crystalline crust. Bodies with densities of $2700 \mathrm{~kg} / \mathrm{m}^{3}$ or less are considered to represent sedimentary rocks. A body with a density of $3150 \mathrm{~kg} / \mathrm{m}^{3}$ may be interpreted to represent eclogite in such an interpretation. In the distal margin, note the rotated, basement-cored fault block and northwestward-rising crystalline basement with pre-Cretaceous cover. In (E), rocks with densities between 3150 and $3100 \mathrm{~kg} / \mathrm{m}^{3}$ are considered to represent retrograde/serpentinised mantle, whereas rocks with densities of $2950 \mathrm{~kg} /$ $\mathrm{m}^{3}$ represent lower crust or serpentinised mantle according to their structural position above or below the DRB. Both configurations are theoretically possible, considering overlaps in density between crystalline crust, serpentinised mantle and dense sedimentary rocks. Whether the area between the south Vigra High and the FaeroeShetland Escarpment is composed of continental crust, crystalline basement or dense sedimentary rocks is not well constrained. $(F)$ is a generalised interpretation that considers a number of the uncertainties associated with the interpretation, including an alternative interpretation of fault blocks and basins between $F_{1}$ and $F_{2}$, in the style of Osmundsen \& Ebbing (2008), but with a preference for a layer of shallow serpentinised mantle under large parts of the Møre Basin. 
Transect 1
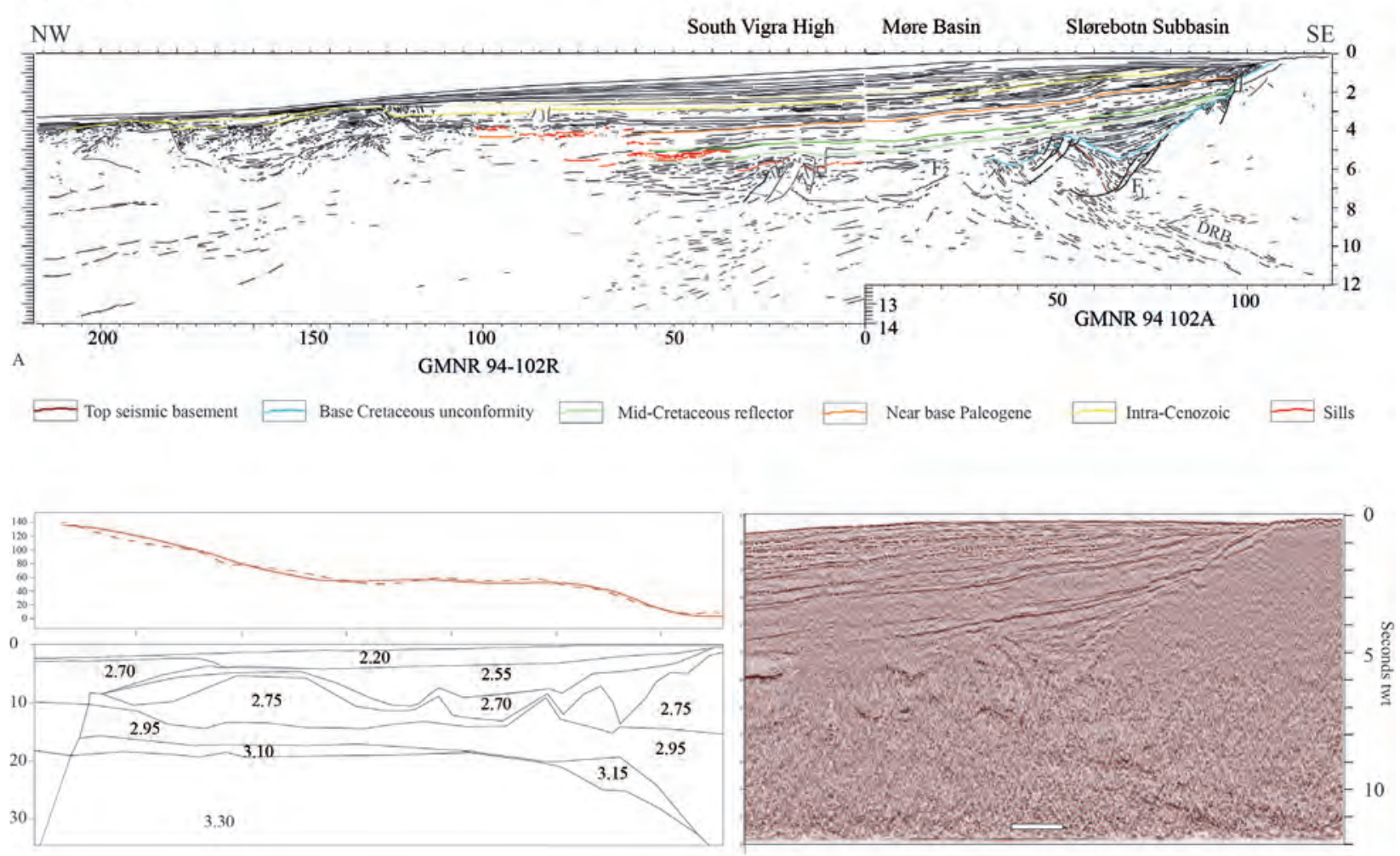

C

B

GMNR94-102A
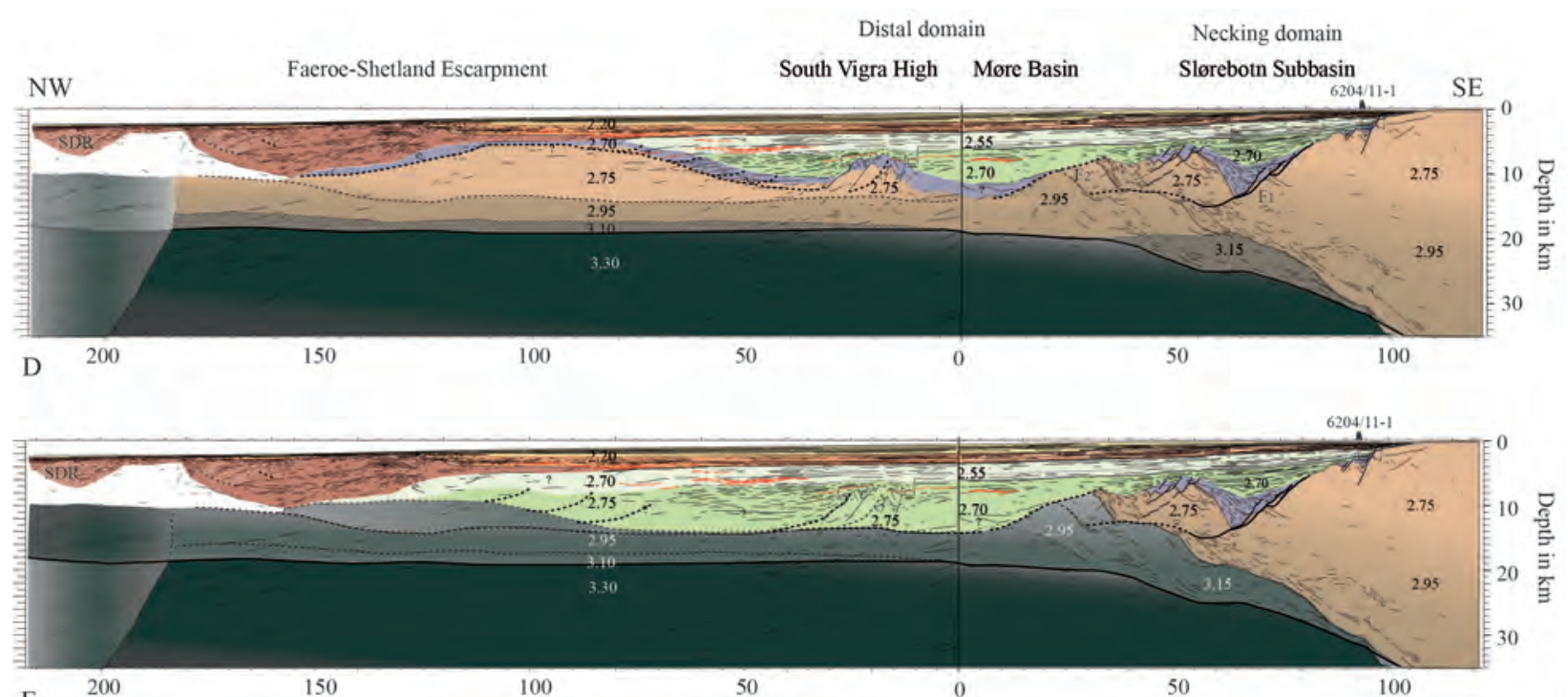
E 200
150
100
50
0
50

100

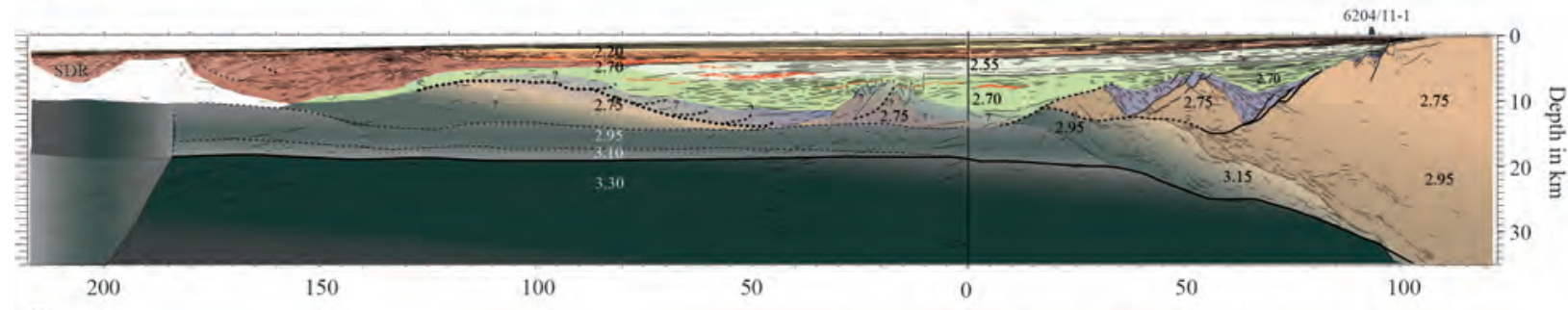

F

Geoseismic sections based on GMNR94-102A and GMNR94-102R (public).

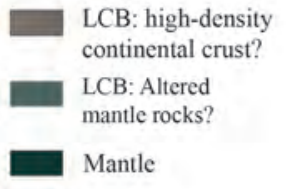

continental crust?
tensity

LCB: Altered

Mantle

Triassic-Jurassic
-L.Cretaceous?
Triassic
Continental crystalline crust/
pre-Mesozoic successions

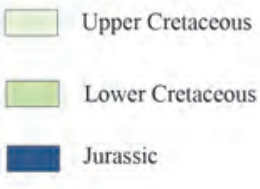

- Sills

Volcanic and intrusive complexes

Denozoic 
The top of basement is well defined and coincides with the subhorizontal seafloor in the southeastern part of the section, but starts dipping basinwards at profile $\mathrm{km}$ c. 105 (SE part). Apart from a small normal fault at profile $\mathrm{km} c$. 95, the top of basement is interpreted as an unconformity onlapped by sedimentary rocks until $\mathrm{km} c$. 80. There, a knickpoint occurs at the top of basement as it becomes defined by a well-imaged large normal fault $\left(\mathrm{F}_{1}\right)$. The heave along $\mathrm{F}_{1}$ is $c .17 \mathrm{~km}$ measured along the seismic line, and the fault has a low to moderate apparent dip where it juxtaposes a rotated pre-Cretaceous basin against the crystalline basement. $\mathrm{F}_{1}$ cuts gently southeastdipping basement reflectivity at $c .10 \mathrm{~km}$ and at $c .15 \mathrm{~km}$ depth, it is incised into a northwest-rising set of reflectors termed here the deep reflector band (DRB). We interpret $\mathrm{F}_{1}$ to have facilitated coupling of deformation from high to low structural levels in the area, constituting a major boundary fault for the south Møre margin. Furthermore, the above-mentioned northwest-dipping unconformity indicates substantial erosion into the footwall of $F_{1}$ and thus the removal of evidence for several kilometres of extension from the section.

The top of basement rises northwestwards in the hanging wall of $F_{1}$ and is cut by faults with moderate offsets. At profile $\mathrm{km} c$. 40, the top of basement again dips moderately northwestwards, and is interpreted as constituting a fault plane or an eroded fault plane $\left(\mathrm{F}_{2}\right)$. A dramatic thinning of crust and/or upper mantle occurs in this area, consistent with the upwards and northwestwards termination of the deep reflector band (DRB). In our interpretation, this is a site of near or complete excision of the continental crystalline crust (Fig. 3).

From c. $30 \mathrm{~km}$, the top of basement is less well defined, but is tentatively placed at the base of reflective sedimentary rocks at the boundary to a more transparent area in the seismic section. Northwestwards, the top of basement can only be interpreted from seismic refraction data and potential field modelling and few structures can be observed. Northwest-dipping normal faults bound a poorly imaged, rotated block between profile $\mathrm{km}$ c. 20 and 70 in GMNR94-102R, in a location along the strike of the Vigra High (Reynisson et al., 2011). It is termed the south Vigra High below. In the northwestern parts of the section, Cenozoic volcanic rocks display impressive lava deltas and seaward-dipping reflectors close to the line of breakup (Fig. 3; Berndt et al., 2001).

The poor quality of the seismic reflection data in the distal areas, together with the small variations in density between the bodies defined in the 3D crustal model, makes interpretation of the pre-Cenozoic levels highly uncertain in the northwestern parts of the section. Several scenarios can be suggested for the continuation of structures and lithological units from the more wellconstrained area in the southeast, depending on the interpretation of the structure and lithology in the betterimaged necking domain.
The lithological configuration in the necking domain and in the deep distal margin in the southeastern parts of our transect is challenging. This is reflected in our three different scenarios for this transect (Fig. 3D-F) and is discussed further below. The marked deep reflector band (DRB) rising from $12 \mathrm{~s}$ twt in the southeastern parts of the section to $c .7 \mathrm{~s} \mathrm{twt}$ farther northwest is interpreted as an important geological boundary. When comparing our seismic interpretation to the first-order potential field model, it appears that the shapes, dips and boundaries of the geological bodies defined through seismic are at odds with those interpreted and modelled from OBS and potential field data (Fig. 3). Based on these observations we envisage two possible end-member scenarios. In Fig. 3D, rocks with density of $2950 \mathrm{~kg} / \mathrm{m}^{3}$ represent continental lower crust, whether they are structurally above or below the northwest-rising deep reflector band. Thus, in this scenario, modelled density bodies have been translated directly into lithology, independent of observed basement structure. The southeast dips of the DRB to $11 \mathrm{~s}$ twt $(33 \mathrm{~km}$ depth in the depth-converted section) and other deep reflectors southeast of $\mathrm{km} 25$ are consistent with structural incision and denudation of very deep levels in the footwalls of the northwestdipping, large-magnitude faults interpreted from the seismic reflection data. We consider it problematic that the DRB, which is interpreted to represent an important structural and/or lithological boundary, should be crossed by a horizontal lithological layer extending from beneath the continent to the continent-ocean boundary. One possibility may be that the culmination-like feature marked by the top of the deep reflector band (DRB) in the footwall of $F_{2}$ represents the poorly imaged top of a rotated fault block (interpretation of Osmundsen \& Ebbing, 2008), or, alternatively, the mylonitic top of a metamorphic core complex consisting of lower crustal rocks. The depth of the DRB in the southeast parts of the section connects it to the crust-mantle boundary, and an alternative interpretation (Fig. 3E) is that rocks with density $2950 \mathrm{~kg} / \mathrm{m}^{3}$ that are structurally below the DRB are interpreted as altered mantle rocks (e.g., deformed, serpentinised, infiltrated). This interpretation honours the continuation of the DRB to mantle depths in the southeast, and also provides an explanation for the transition from densities of 3100 to $2950 \mathrm{~kg} /$ $\mathrm{m}^{3}$ in the body below it, because a southeast-dipping, altered mantle body may well contain a transition from more to less serpentinised mantle with depth. An implication would be that the rocks structurally below the DRB, thinning into a $c .5 \mathrm{~km}$ thick layer of rocks under the Møre basin, also represent altered mantle, or a mix between exhumed serpentinised mantle and crustal blocks. Considering recent interpretations from the Iberia-Newfoundland margin pair (e.g., PéronPinvidic et al., 2013) we hold this interpretation as quite likely. However, it would imply, firstly, a body of altered mantle that is very thick $(10 \mathrm{~km}$ at profile $\mathrm{km}=30)$ and, secondly, that parts of this body occur in a position where theoretically, little water could reach the mantle to result 
in serpentinisation (i.e., under the unfaulted crustal section east of profile $\mathrm{km}=65$ ). In such a scenario, pervasive deformation and/or melt infiltration and stagnation may provide alternative explanations for the modified geophysical characteristics. Our model in Fig. $3 \mathrm{~F}$ incorporates a number of the uncertainties discussed above, but has a preference for a Jurassic-Cretaceous, crust-mantle boundary closer to the scenario in Fig. 3E rather than to that in Fig. 3D, with the body of 3150 $\mathrm{kg} / \mathrm{m}^{3}$ density under the necking domain representing altered mantle and a layer of altered mantle (potentially with crustal blocks) under the deepest parts of the Møre Basin. The structural configuration at depth northwest of the south Vigra High is highly uncertain due to poor imaging. However, in other parts of the GMNR94 survey, rotated fault blocks are well or fair imaged at depth in the deep basins. We therefore suspect that fault blocks west of the south Vigra High in the present section would be small and dominated by sedimentary rocks, as in the more northeastern parts of the Møre basin (see below) or, alternatively, entirely absent.

\section{Basin configuration}

Triassic and Jurassic sedimentary rocks were penetrated by the exploration well 6204/11-1 at profile $\mathrm{km} c$. 90-95 in the southeastern parts of the section, where they are preserved in a small Cretaceous half-graben and place some constraint on the depth of erosion into the footwall of $F_{1}$. The rotated half-graben basin in the hanging wall of $\mathrm{F}_{1}$ hosts a c. 5-6 km-thick, wedge-shaped succession of presumed pre-Cretaceous sediments. The deepest parts of this synrift basin overlie the hanging wall cutoff for $\mathrm{F}_{1}$ at $c$. 14 kilometres depth. The basin is capped by an unconformity, tentatively interpreted to represent the base of the Cretaceous. Northwest of $\mathrm{F}_{2}$, the distribution of pre-Cretaceous sediments is less certain from the seismic reflection data. A pre-Cretaceous, half-graben basin geometry can be suggested between $\mathrm{F}_{2}$ and the south Vigra High, based on scattered reflectors in the long-offset seismic data and on a modelled density increase below c. $8-10 \mathrm{~km}$ depth southeast of the high. The presence of high-density Cretaceous strata in other parts of the margin (see below) makes this interpretation highly uncertain, and highlights the principle that density cannot distinguish the age of strata, only the degree of compaction. Northwest of the high, GMNR94-102R does not reveal much information below the interpreted subhorizontal Cretaceous strata.

The main parts of the Cretaceous basin overlie and onlap the top of basement in the southeastern parts of the section and downlap onto the top of the assumed pre-Cretaceous half-graben in the hanging wall of $F_{1}$. West of $F_{2}$, the base of the Cretaceous basin is virtually unconstrained, but flat-lying or gently dipping reflectors are interpreted to represent sedimentary strata down to at least $12 \mathrm{~km}$ depth (Fig. 3). Subhorizontal reflectivity prevails in the Cretaceous towards central parts of the section, where overlying igneous rocks destroy data quality in the underlying section. Northwest of the south Vigra High, modelled northwest-rising density boundaries (between densities of 2550, 2700 and 2750 $\mathrm{kg} / \mathrm{m}^{3}$ ) may indicate the presence of crystalline basement and/or intruded pre-Cretaceous sedimentary rocks (Fig. 3D), or alternatively, a density gradient inside the Cretaceous basin (Fig. 3E). A northwest-rising detachment fault overlain by rotated fault blocks was interpreted farther northeast in the Møre Basin (see below) and the stippled lines between profile $\mathrm{km} 50$ and $150 \mathrm{~km}$ in GMNR94-102R explore this possibility also in the present section, based on modelled densities but not on the reflection seismic.

\section{Transect 2: Northeast Møre Basin}

Fig. 4 shows our two-way time interpretation of the structural and stratigraphic architecture of the northeasternmost part of the Møre Basin, and comprises our interpretation of the long-offset GMNR94-103 line (Fig. 4A, B), as modified from Osmundsen \& Ebbing (2008).

\section{Basement structure}

The exploration well 6306/10-1 was drilled to metamorphic basement. Northwest of the well, a smooth, NW-dipping top basement reflector is interpreted to represent a large-magnitude normal fault which marks the boundary to the distal margin in the northeast Møre Basin area (Main Møre boundary fault of Osmundsen \& Ebbing, 2008). Northwest of the hanging wall cutoff, the top of basement dips gently southeastwards forming the top of a large, rotated fault block (Fig. 4). The fault-plane reflector continues as a reflector band inside the basement, where it cuts another set of deep reflectors interpreted to represent reflective lower crust at c. $9 \mathrm{~s}$ twt. The displacement on the MMF appears to be in the order of $40 \mathrm{~km}$ along the line of section, which is oblique to the local fault strike. A true displacement of $25-30 \mathrm{~km}$ can be confidently interpreted based on neighbouring lines with more orthogonal orientations. A convex-upward reflector band is identified inside the basement underneath the fault block that hosts 6306/0-1; it joins the northwest-dipping top of basement at $c .5 \mathrm{~s}$ twt, indicating that it is incised by the MMF. On parallel seismic profiles, the reflector band can be traced southwestwards beneath rotated fault blocks in the Slørebotn subbasin area, where it was interpreted as a flatlying extensional detachment by Jongepier et al. (1996). The incision of a Late Jurassic, warped detachment fault by the main boundary fault to the distal margin indicates that in the necking domain at the northeastern Møre margin, the process of downwards coupling deformation involved several stages of faulting (Osmundsen \& Ebbing, 2008). 
Transect 2

NW

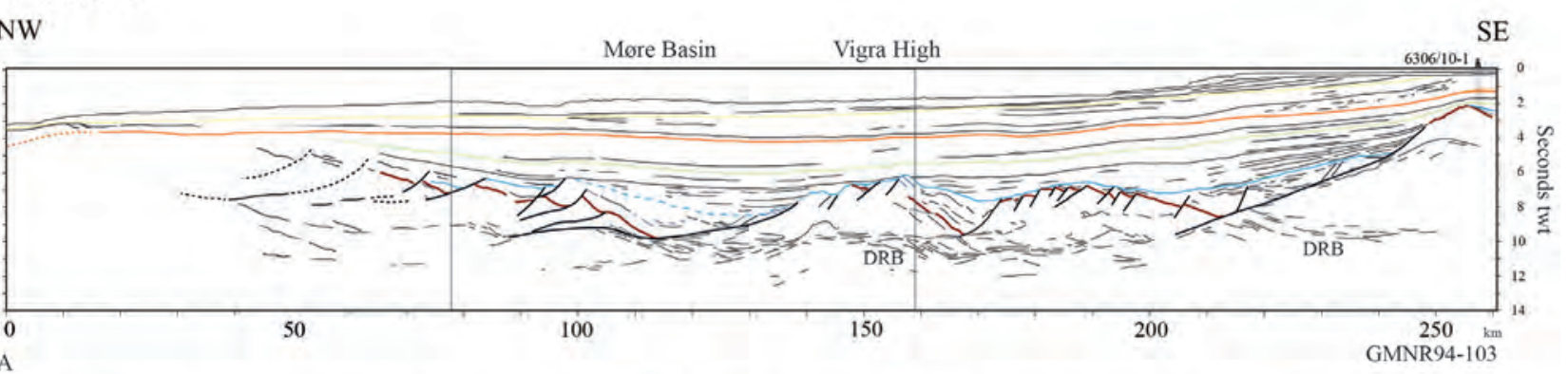

A

$\square$ Top seismic basement $\square$ Near base Paleogene $\square$ Mid-Cretaceous reflector $\quad \square$ inconformity $\quad \square$ Intra-Cenozoic
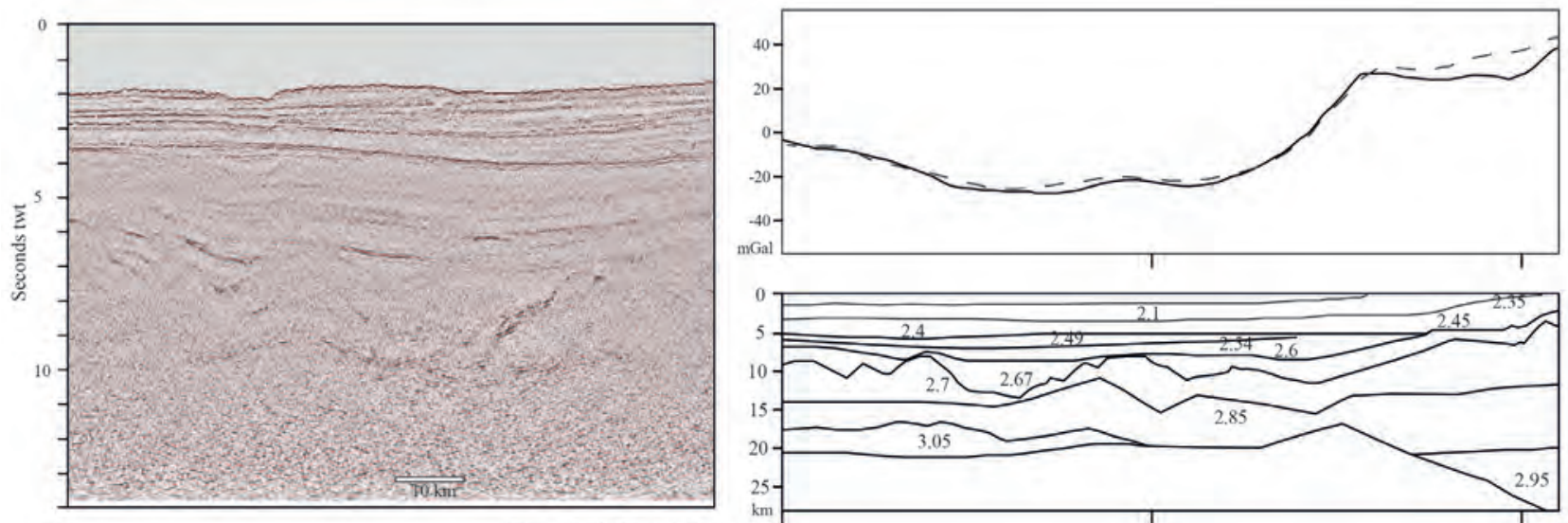

Part of GMNR94-103
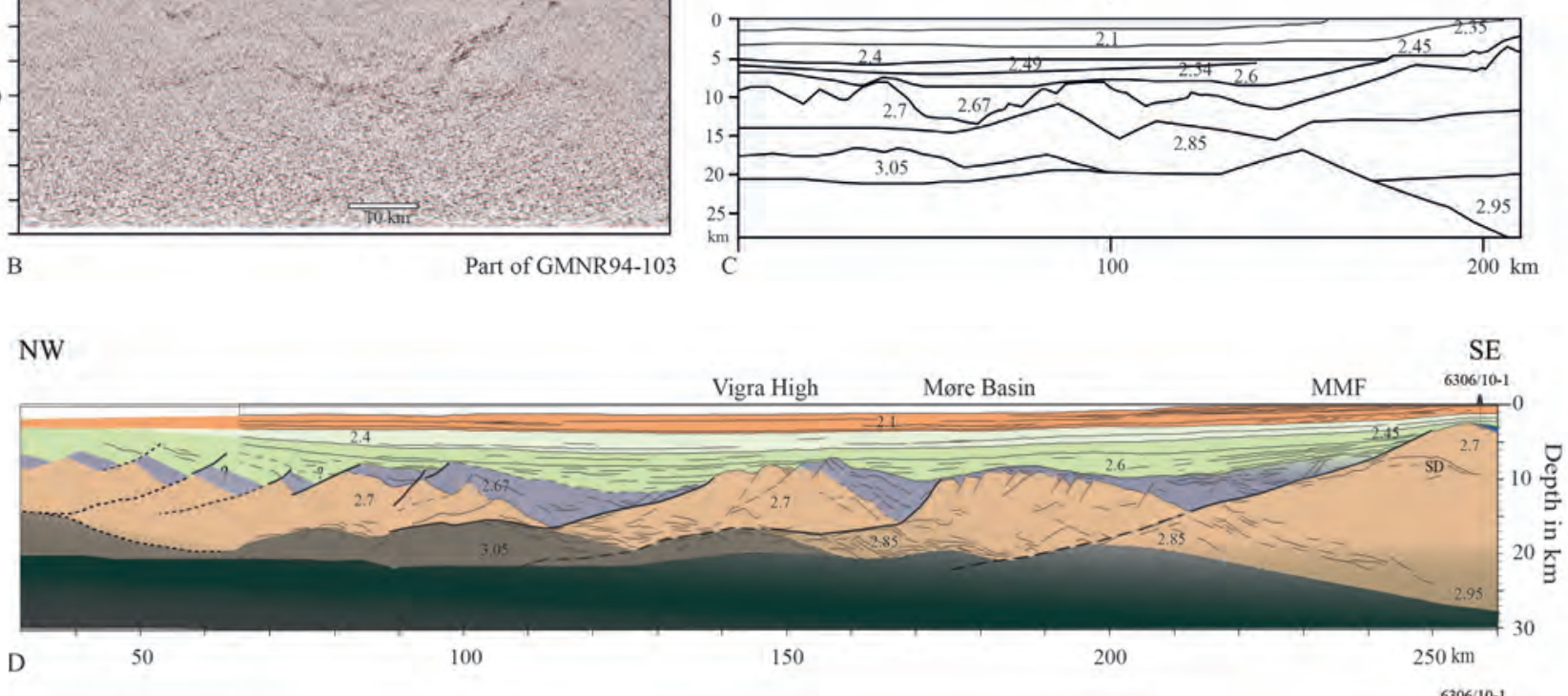

D

100

150

6306/10-1

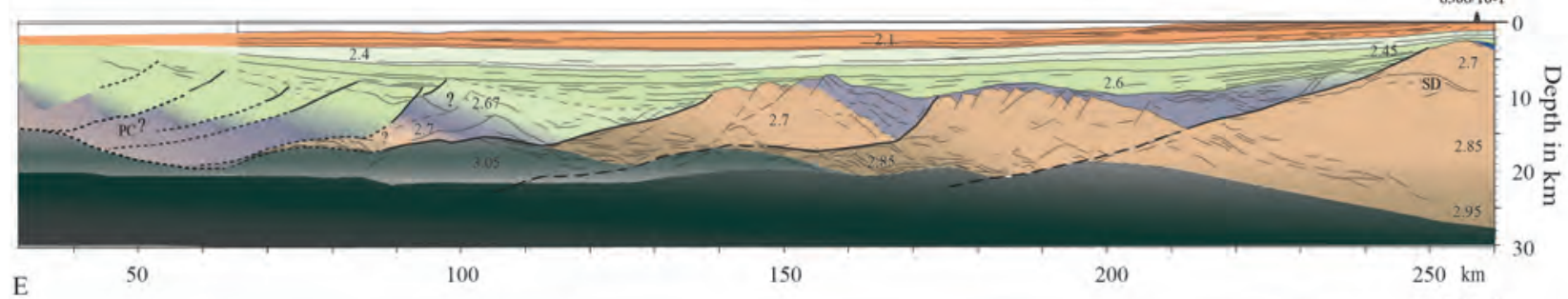

E

100

150

200

6306/10-1

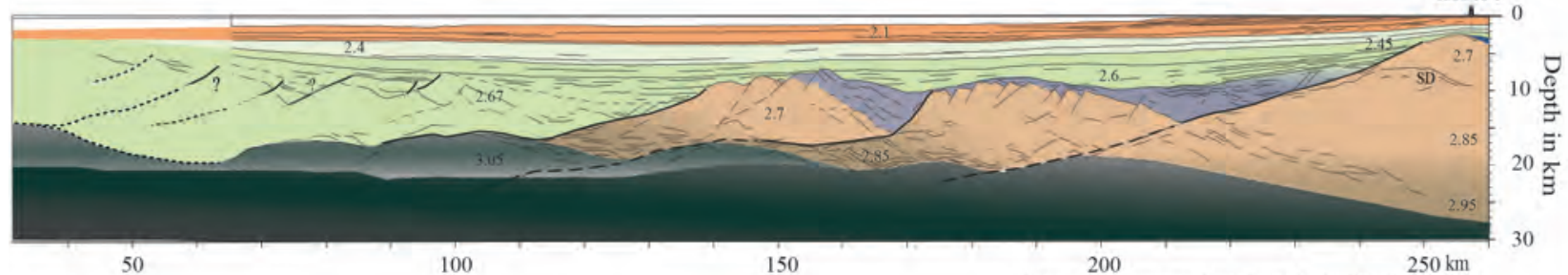

LCB: Altered mantle rocks

Mantle
Continental crystalline crust pre-Mesozoic successions

LCB: High-density continental crust
Jurassic

Triassic-Jurassic -L.Cretaceous?
Upper Cretaceous

Cenozoic

] Lower Cretaceous 
The fault that bounds the Vigra High in the northwest has an apparent minimum displacement in the order of $20-25 \mathrm{~km}$ and incises the DRB. The fault is interpreted to continue northwestwards, rising towards the breakup area. This interpretation is justified by a vague reflector in the GMNR94-103 section, but is better substantiated by more recent, proprietary, deep-seismic reflection data recorded in the northwestern parts of the Møre Basin (not shown, see acknowledgements). In the hanging wall of the rising detachment, a rotated allochthon can be readily interpreted between profile $\mathrm{km} c .80$ and 110 . In the interpretation of Osmundsen \& Ebbing (2008), the allochthon is capped by rotated Cretaceous and older strata underlain by a reflector designated as top seismic basement. In Fig. 4D, this is equated with the top of crystalline basement. In our alternative scenarios (Fig. 4E, F), however, this reflector more likely represents the top of denser sedimentary rocks. On the northwest side of the allochthon, at $\mathrm{km} 75-85$, a fault with a displacement of c. $8 \mathrm{~km}$ offsets the Lower Cretaceous stratigraphy. Northwest of this point, 3-4 more normal faults are interpreted above the rising detachment fault. A high-density, high-velocity, 'lower crustal body' (LCB) was modelled under rotated fault blocks in the western

Figure 4. Transect 2. (A) Two-way time interpretation of long-offset seismic reflection profile GMNR94-103 from the northeast Møre Basin (modified from Osmundsen \& Ebbing, 2008). Note deep reflector band (DRB), interpreted to represent reflective lower crust, offset by low-angle extensional faults including the Main Møre boundary fault (MMF), which has a true displacement of 25-30 km. Note also extensional detachment constituting the northwestern boundary of the Vigra High. The continuation of this detachment truncates the deep reflector band and offsets it. The stratigraphy northwest of the Vigra High is unconstrained in its lower parts. Inset rectangle marks location of seismic image in (B). (B) Seismic detail from GMNR94103 showing seismic image of detachment fault northwest of the Vigra High. The detachment incises into the deep reflection band at a low angle and is subhorizontal under the fault blocks northwest of the high, rendering them extensional allochthons. (C) Density model extracted from $3 D$ crustal model along line of section. (D-F) represent alternative interpretation scenarios for the north Møre transect, modified from Osmundsen \& Ebbing (2008). Versions in (D) and (E) represent end-member scenarios with respect to crustal thinning. Note that, in both scenarios, rotated fault blocks northwest of the Vigra High are underlain by a northwestward-rising detachment (see text). (D) The top of crystalline basement is relatively shallow northwest of the Vigra High, corresponding to the top of seismic basement in Osmundsen \& Ebbing (2008). In this interpretation, crustal thickness increases towards the outer margin. (E) Top of basement northwest of the Vigra High comprises the detachment that underlies the rotated fault blocks, which are entirely Cretaceous in this scenario. (F) Generalised interpretation that considers some of the uncertainties in the interpretations but with a preference for a deep-seated top of basement that may become completely removed in the northwestern parts of the section. The rotated fault blocks may contain Lower Cretaceous rocks in their upper parts and, possibly, pre-Cretaceous sedimentary rocks at depth. parts of the section (Osmundsen \& Ebbing, 2008). As with other LCBs proposed for the margin, its origin is uncertain (e.g., Mjelde et al., 2009b; Lundin \& Doré, 2011). We follow previous suggestions by Osmundsen \& Ebbing (2008) and Lundin \& Doré (2011) that it may represent altered mantle as it is affected by, and largely bounded by, the faults that separate rotated blocks in the hyperextended domain.

\section{Basin configuration}

The section shows wedge-shaped reflector packages interpreted as synrift sedimentary rocks. The rocks affected by faulting appear to become younger towards the northwest. In the southeastern parts of the section, a Jurassic synrotational wedge was sampled by 6306/10-1. Above and northwest of the hanging wall cutoff, thicker, wedge-shaped, reflector packages are juxtaposed against the MMF and other normal faults underneath the 'Base Cretaceous' unconformity. They are mainly interpreted to represent Late Jurassic and older synrift strata, but the presence of Early Cretaceous strata can be argued based on margin-wide interpretations and arguments (e.g., Lundin \& Doré, 1997; Doré et al., 1999). Northwest of the Vigra High, rotated fault blocks become smaller and appear as allochthons on the northwest-rising detachment fault. The top of basement can no longer be identified with confidence in this area, and the thickness and age of basin strata between the Lower Cretaceous reflectors and the interpreted detachment fault remains uncertain. The progressive downfaulting of Lower Cretaceous strata above the detachment indicates that there may be less and less 'synrift', pre-Cretaceous rocks preserved towards the northwest in the section (Fig. 4E, F).

The overlying Cretaceous succession drapes and downlaps onto rotated fault blocks at depth, and landwards, it onlaps the MMF at low angles. The upper units in the Cretaceous succession sampled by well 6306/10-1 oversteps and buries the MMF as well as less significant normal faults southeast of the well. Cenozoic sedimentary rocks cover most of the section, but a large part of the succession is warped and cut by the Quaternary seafloor in the southeast.

\section{Transect 3: South Vøring Basin}

This transect is well suited to illustrate the deep structure under the Halten Terrace as well as parts of the distal margin domain in the south Vøring area. Our two-way time interpretation (Fig. 5A) and one of the alternative scenarios presented for the transect (Fig. 5D) were based on a previous interpretation (Osmundsen \& Ebbing, 2008) of the long-offset seismic reflection profiles GMNR94-104 and GMNR94-104R. 
Transect 3
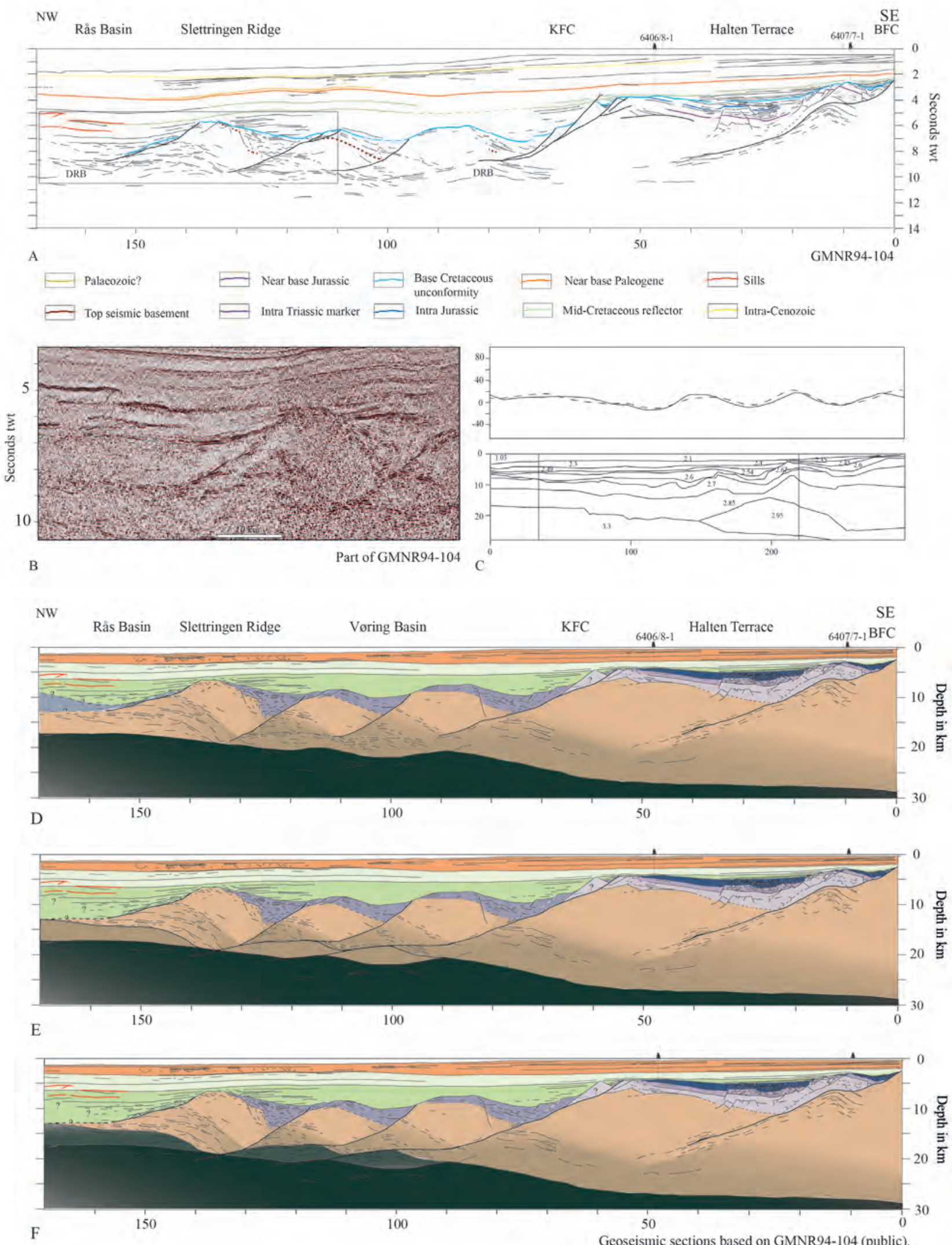

F

LCB: Altered mantle rocks

Mantle
Continental crystalline crust pre-Mesozoic successions

Mid-late Triassic
Mid - to lower Triassic and older

Triassic-Jurassic -L.Cretaceous? 


\section{Basement structure}

The transect presents a more gradual reduction of crustal thickness than observed in the Møre margin, and thus a gentler taper for the crystalline crust. At the border between the Trøndelag Platform and the southern Halten Terrace, the top of basement is downfaulted in the hanging wall of a ramp-flat detachment, the Bremstein Fault Complex (BFC), which continues at depth underneath the Halten Terrace. In the footwall of the detachment, a reflector band likely to represent basement rocks deformed in the ductile domain is deflected into a culmination that underlies the flat part of the detachment at $c .4 \mathrm{~s}$ twt, indicating an extensional culmination or core complex (Osmundsen et al., 2002; Ehrlich \& Gabrielsen, 2004). A reflector band continues to great depth along the continuation of the BFC. The top of basement is further downfaulted along the Klakk Fault Complex (KFC), which defines the boundary fault between the necking and distal margin domain in the south Vøring Basin, and which has a total displacement in the order of $15-20 \mathrm{~km}$ in this part of the margin (Fig. 5). The inner parts of the south Vøring Basin comprise an array of rotated crustal fault blocks which range in thickness from $<5$ to $12 \mathrm{~km}$. Most of this area thus consists of hyperextended crust, and belongs to the hyperextended subdomain (Péron-Pinvidic et al., 2013) of the distal margin. The block-bounding faults detach in laminated

Figure 5. Transect 3. (A) Two-way time interpretation of parts of long-offset reflection lines GMNR94-104 and GMNR94-104R from the southern Vøring Basin, modified slightly from Osmundsen \& Ebbing (2008). Whereas crystalline basement rocks were encountered in the well 6306/10-1, basement control is poorer in the northwestern parts of the section, as reflected in the alternative interpretation scenarios below. (B) Inset seismic detail showing listric detachment fault bordering a rotated fault block in the hyperextended subdomain of the distal margin (Vøring Basin). Note dipping reflectors above the detachment northwest of the Slettringen Ridge, interpreted to represent southeastward-dipping beds, and southeastdipping reflectors below (and terminated against) the detachment, which may tentatively represent the Jurassic-Cretaceous crustmantle boundary. (C) Density model extracted from the 3D crustal model along the line of section. (D-F) present different interpretation scenarios for GMNR94-104. The scenario in (D) corresponds to the interpretation in Osmundsen \& Ebbing (2008), which had a thin layer of continental crust continuing from the Slettringen Ridge in the direction of the Jan Mayen Fracture Zone. In (E), we have reinterpreted the fault traces in a manner more compatible with the twoway time interpretation in $(A)$. In this interpretation, the array of fault blocks correspond to a hyperextended subdomain in the rifted margin, with deformation coupled between the crust and mantle. In (F) we have placed the Jurassic-Cretaceous crust-mantle boundary at the set of southeast-dipping reflectors that joins the detachment west of the Slettringen Ridge. In this interpretation, mantle would have become serpentinised and exhumed under the hyperextended subdomain and under the large supradetachment basin interpreted northwest of the Slettringen Ridge. Abbreviations: DRB - Deep reflector band, KFC - Klakk Fault Complex, BFC - Bremstein Fault Complex. lower crust or cut it and continue into the mantle. In our interpretation, the latter situation applies in particular for the 2-3 outermost faults in the array (Fig. 5A, B). Along the northwestern flank of the Slettringen Ridge, a major fault breakaway passes into a subhorizontal detachment with displacement in the order of tens of kilometres in the less well-imaged area towards the Jan Mayen Fracture Zone (e.g., Osmundsen et al., 2002; Osmundsen \& Ebbing, 2008). At depth northwest of the Slettringen Ridge, deep reflector bands rise northwestwards to be cut by the proposed detachment. This indicates that the detachment cuts progressively deeper into the footwall rocks in this direction, and we hold it likely that one of these reflector bands (Fig. 5A, B) represents the Jurassic-Cretaceous crust-mantle boundary.

\section{Basin configuration}

The Halten Terrace hosts basins of Triassic and Jurassic age and is a prolific hydrocarbon province. Detailed descriptions of structures and basins in the Terrace area can be found elsewhere (e.g., Brekke, 2000; Marsh et al., 2010). We interpret the general geometry of the southern Halten Terrace (Fig. 5) to reflect the shape of the underlying ramp-flat detachment fault (see also Ehrlich \& Gabrielsen, 2004). West of the Klakk fault complex, the hyperextended subdomain contains a series of wedge-shaped half-graben basins onlapped by strata in the overlying postrift basin. The rotated half-graben basins resemble those in the northeast Møre Basin and similar to those the age of the half-graben basin fills are not well constrained. It is, for example, unknown whether Lower Cretaceous rocks are also downfaulted into the half graben. In this case, the ' $\mathrm{BCU}$ ' is not the $\mathrm{BCU}$ sensu strictu through the entire margin.

The detachment that bounds the Slettringen Ridge in the northwest floors a deep sedimentary basin in our interpretation, which is contrary to the interpretation of Nirrengarten et al. (2014) who preferred to interpret this interval as continental crystalline crust. Southeastward-rotated reflectors, probably representing pre-Cretaceous or Cretaceous rocks, are imaged c. 30 $\mathrm{km}$ northwest of the ridge beyond the area of Fig. 5 . They indicate that the Rås Basin hosts rotated fault blocks of unknown composition, likely pre-Cretaceous or Cretaceous sediments, onlapped by Cretaceous strata. The morphology of this part of the margin, with coupled, half-graben bounding faults in hyperextended continental crust bordered by a breakaway transitional into a subhorizontal detachment fault that cuts deepseated, continent-dipping reflectors, resembles that of the outer Iberian margin (Péron-Pinvidic et al., 2007 and below). Although this does not itself prove that mantle became exhumed under Mesozoic deposits northwest of the Slettringen Ridge, we hold it likely. We also observe that above the flat detachment, sill intrusions become abundant in the Cretaceous basin. 


\section{Transect 4: Central Vøring Basin}

This transect was constructed from the seismic reflection profile MNR05-7300 (Fig. 6A, B). The section is generally of very good to excellent quality, with exception of the deepest parts of the Rås Basin. It is well suited to address the structural setting of the Rån Ridge, in particular its trailing (southeastern) edge, and the geological significance of the so-called ' $\mathrm{T}$ '-reflector.

\section{Basement structure}

In the Trøndelag Platform area, there is good agreement on the boundary between layers of density $2650 \mathrm{~kg} /$ $\mathrm{m}^{3}$ and $2800 \mathrm{~kg} / \mathrm{m}^{3}$ modelled from the potential field data and the top of a double reflector interpreted tentatively as the top of Mid or Late Palaeozoic deposits (Osmundsen et al., 2002; Müller et al., 2005). An up to 5-6 kilometre-thick succession of possible pre-Triassic (?), Triassic and Jurassic rocks underlie the Platform and Terrace areas (Fig. 6D-F), in accordance with previously published models (e.g., Breivik et al., 2011). The modelled Moho rises gently from $>30 \mathrm{~km}$ to $c .27$ $\mathrm{km}$ between the southeastern parts of the section and c. $270 \mathrm{~km}$. Cretaceous accommodation correspondingly increases abruptly at $270 \mathrm{~km}$, and the inner boundary for the necking domain is represented by the Revfallet Fault Complex (Blystad et al., 1995) at the western boundary of the Nordland Ridge.

Under the Dønna Terrace, the Moho rises sharply northwestwards to a depth of c. $22 \mathrm{~km}$ and appears to nearly converge with the top of basement along the Ytreholmen Fault Zone of Blystad et al. (1995), which juxtaposes the Dønna Terrace with the very deep Cretaceous Rås Basin (Fig. 6). Thus, the Dønna Terrace and Ytreholmen Fault zone comprise the necking domain in this part of the Vøring margin.

The Ytreholmen Fault zone (YFZ) is interpreted as a large-magnitude extensional fault complex characterised by triangular fault rider blocks, although not well imaged in the seismic reflection data. The angle between basinward-dipping Cretaceous strata and the interpreted and modelled basement slope indicates that the proposed detachment was active at a low angle or acquired a low angle shortly after its main phase of activity. The structure of the YFZ may be significantly more complex than our simple interpretation, but the seismic reflection data do not reveal much detail. The transect crosses the Ytreholmen Fault zone obliquely, and the apparent $50-60 \mathrm{~km}$ of total displacement may exceed the true displacement. A body with density of $3100 \mathrm{~kg} / \mathrm{m}^{3}$ was modelled under the northwesternmost parts of the Rån Ridge. The top of this body reaches $c .17 \mathrm{~km}$ depth in the depth-converted section. If this body represents serpentinised mantle rocks, the continental crystalline crust may have been tectonically removed along parts of the Ytreholmen Fault zone (Fig. 6E, F).

Northwest of the Rås Basin, a triangular basement ridge is bound to the southeast by the Fles Fault Complex (FFC; Blystad et al., 1995), and to the northwest by a planar, northwest-dipping segment of the so-called ' $\mathrm{T}$ '-reflector (Gernigon et al., 2004), interpreted here as a low-angle detachment fault (Fig. 6A, B, D-F). The FFC cuts and displaces basement and Early Cretaceous strata landwards, probably by several kilometres; the hanging wall cutoff of basement cannot be identified at depth in the reflection data from the Rås Basin. The detachment

Figure 6. Transect 4. (A) Two-way time interpretation of the longoffset seismic reflection profile MNR05-7300 from the Vøring basin. The Ytreholmen Fault zone is interpreted as a major breakaway for a detachment that bounds and, most likely, underlies the very deep Rås Basin. Inset rectangle marks location of seismic figure in (B). (B) Inset seismic detail shows segment of the ' $T$ '-reflector interpreted to represent an extensional detachment fault (Td) overlain tectonically by the Rån Ridge as well as by another, smaller, extensional allochthon. The detachment resembles the flat-lying detachments that exhumed serpentinised mantle in areas such as the Iberian margin (e.g., Manatschal, 2004; Péron-Pinvidic \& Manatschal, 2009). The detachment is interpreted as cut and displaced continentwards by the Fles Fault Complex (FFC). The low angle between the detachment and strata in the overlying 'sag' basin indicates that the fault was subhorizontal in the Early Cretaceous, shortly after its main phase of activity. (C) Density model constructed along transect 4 based on published seismic refraction data and potential field modelling. $(D-F)$ Alternative interpretation scenarios for transect 4. Crosses represent seismic velocities obtained from published OBS interpretations (Mjelde et al., 2009a). Colours: green $-5 \mathrm{~km} / \mathrm{s}$, yellow - $6 \mathrm{~km} / \mathrm{s}$, red $-7 \mathrm{~km} / \mathrm{s}$, violet $-8 \mathrm{~km} / \mathrm{s}$. Note that in the proximal margin, the 6 $\mathrm{km} / \mathrm{s}$ mark corresponds to the top of basement or pre-Middle Triassic sedimentary rocks whereas in the Rås Basin, velocities of $6 \mathrm{~km} / \mathrm{s}$ appear to occur in deep-seated basin strata. In (D), rock bodies with modelled densities between 3100 and $2650 \mathrm{~kg} / \mathrm{m} 3$ are interpreted to represent continental crystalline crust. Crystalline crust underlies the triangular block delineated between the Fles Fault Complex and the extensional detachment described above. Crystalline crust also cores the Rån Ridge, which is capped by pre-Cretaceous sedimentary rocks. In (E), the crystalline crust in the triangular block between profile $\mathrm{km} 100$ and 150 has been replaced by serpentinised mantle. The geological implication of this scenario is that the crystalline crust would have to be completely excised by the Ytreholmen Fault Complex (YFC) and its continuation as a flat detachment under the Ras Basin and Rån Ridge. The Rån Ridge would thus be an extensional allochthon resting on a mantle detachment. Serpentinisation would have to be substantial to reduce the density to the modelled $2800 \mathrm{~kg} /$ $m 3$. In scenario $(F)$, all continental crust was removed west of the Ytreholmen Fault zone and transported out of section. The Voring Basin is underlain by serpentinised mantle, which also cores the Rån Ridge. Moreover, sedimentary rocks in the Rån Ridge area all belong to the Cretaceous succession in this scenario. This configuration would require at least two generations of 'exhumation' detachments in the Rain Ridge area, as the ridge itself would contain an inherited tectonic contact between serpentinised mantle and Cretaceous sedimentary rocks. A more detailed discussion of the structural setting of the Rån Ridge is presented in Péron-Pinvidic et al. (submitted). Abbreviation: RFC - Revfallet Fault Complex. 
Transect 4

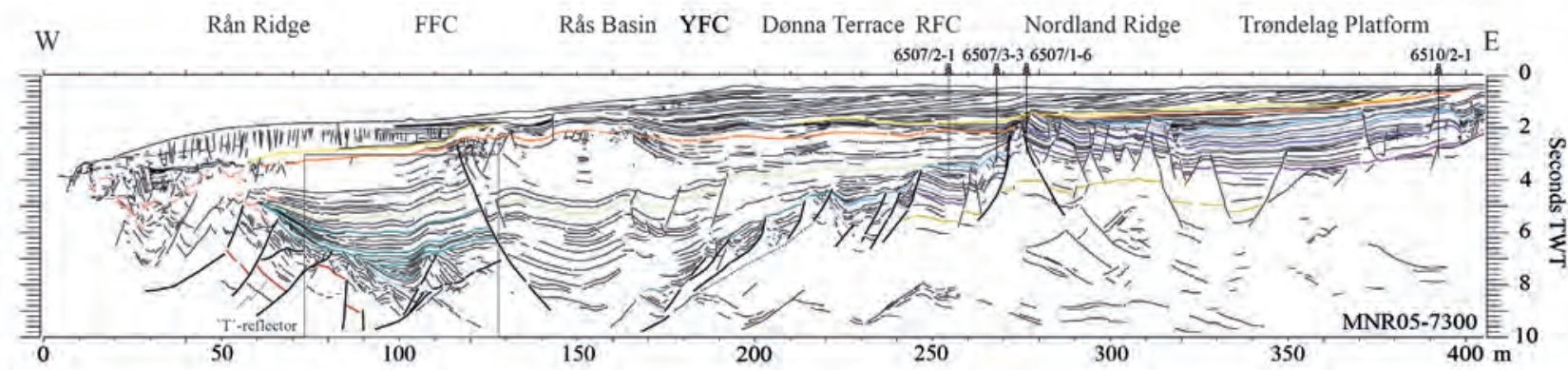

$\begin{array}{lll}\square \text { Palaeozoic? } & \square \text { Near base Jurassic } \square \text { Lower Cretaceous } \square \text { Near base Paleogene } \\ \text { reflectors } & \begin{array}{l}\text { Base Cretaceous } \\ \text { unconformity }\end{array}\end{array}$

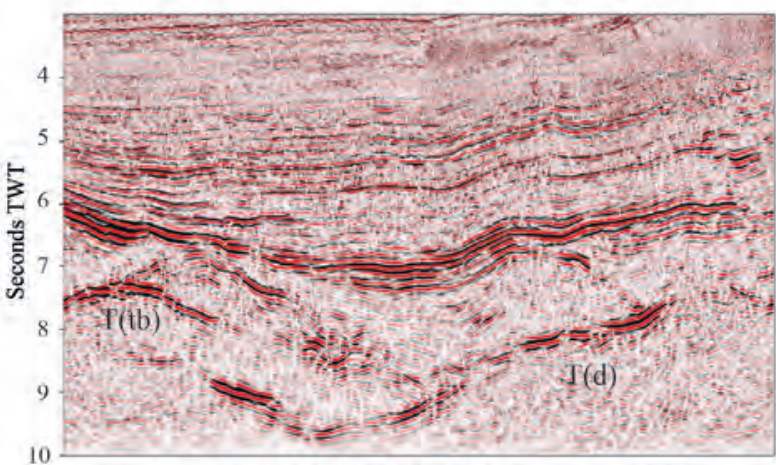

Part of AMR_MNR05-7300, courtesy TGS/Spectrum
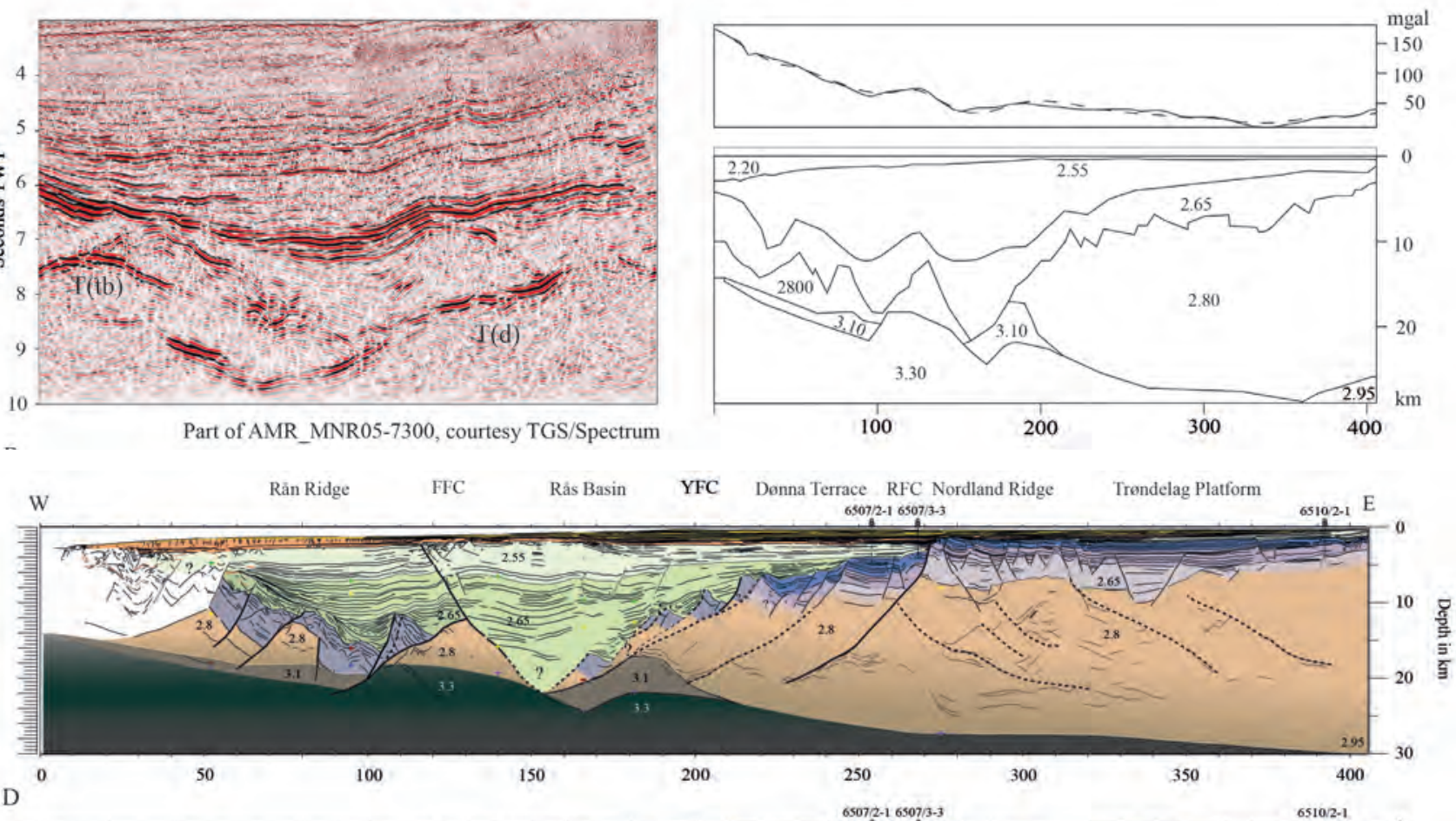

D

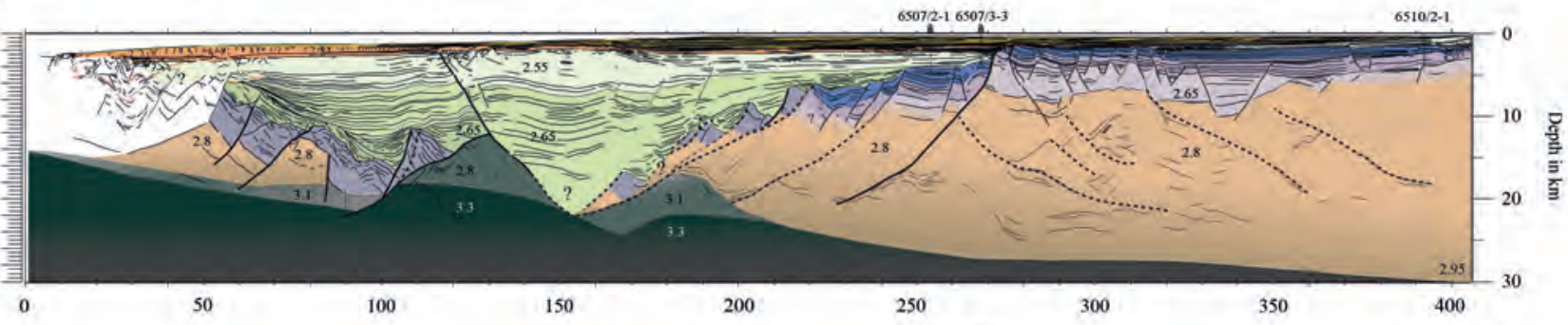

50

100

6507/2-1 6507/3-3

65102-1

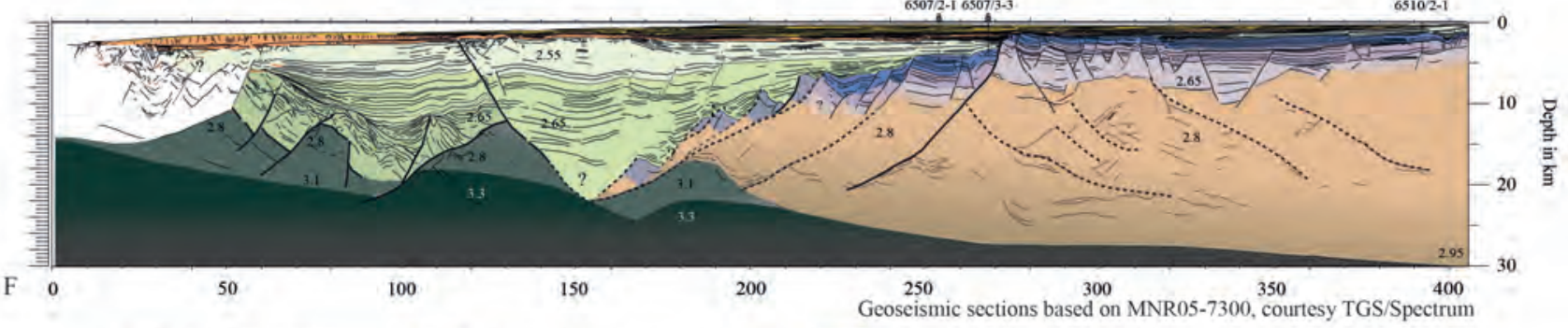
LCB: high-density continental crust?
LCB: Altered mantle rocks?
Mantle

Middle-Upper Triassic

Lower-Middle Triassic and ?older

Continental crystalline crust pre-Mesozoic successions
Lower Cretaceous

Sills

Jurassic

Triassic-Jurassic -L.Cretaceous?

\section{总}

\section{옳}

(n)


fault defines the top of the triangular-shaped basement west of the FFC, but is interpreted to dip underneath the Rån Ridge at $c .92 \mathrm{~km}$ (Fig. 6A). A southeast-dipping reflector package interpreted as a rotated allochthonous rider block is perched on the detachment fault between the FFC and the Rån Ridge. In our interpretation, the Rån Ridge itself is an extensional allochthon, albeit of large proportions. The low angle between the detachment fault and overlying sedimentary layers in the presumed Cretaceous succession indicates that it was active at a very low or subhorizontal dip, or acquired such a low dip shortly after its main phase of activity. The present, westward dip was evidently acquired at a later stage during slip along the FFC or formation of the HellandHansen dome. The Fles Fault Complex appears to have displaced an originally subhorizontal, large-magnitude detachment fault complex (the Ytreholmen Fault zone) that was continuous or segmented, but that may have extended from the northwestern edge of the Dønna Terrace to the trailing edge of the Rån Ridge.

Northwest of $\mathrm{km} \mathrm{c}$. 92, the ' $\mathrm{T}$ '-reflector rises in what is interpreted here as the hanging wall to the above-mentioned detachment. Thus, regionally, the ' $\mathrm{T}$ '-reflector is clearly composed of several tectonic/ lithological features: here, it represents both a detachment fault and the top of basement in its hanging wall.

Lithologically, several alternatives can be considered for the Rås Basin area, the ' $T$ '-reflector and the Rån Ridge. End-member interpretations are shown in Fig. 6. The significance of the ' $\mathrm{T}$ '-reflector is discussed more thoroughly in Péron-Pinvidic \& Osmundsen (2016).

\section{Basin configuration}

In the platform areas, exploration wells constrain an up to $4 \mathrm{~km}$-thick Jurassic into Mid Triassic section, which is underlain by an equally thick (or thicker) succession of presumed Permo-Triassic and possibly older rocks (e.g., Müller et al., 2005). The top of basement is placed at the top of a strong reflector that corresponds to the transition to velocities above $6 \mathrm{~km} / \mathrm{s}$ in the OBS data and to the boundary between rocks with modelled densities of 2.65 and $2800 \mathrm{~kg} / \mathrm{m}^{3}$, respectively. In the deep basin areas, the configuration of density bodies is interpreted somewhat differently, supported by the seismic reflection profiles. There, sedimentary rocks with modelled densities of $2650 \mathrm{~kg} / \mathrm{m}^{3}$ appear as occurring in the Cretaceous basin, and crossing OBS profiles indicate seismic velocities between 5 and 6 at progressively higher stratigraphic levels in the direction of the line of breakup (Fig. 6D). Densities and seismic velocities of the sedimentary rocks do not indicate age per se but rather reflect burial depth and primary thermal history.

Across the Revfallet Fault Complex, accommodation increases in the Cretaceous, and from the western parts of the Dønna Terrace and into the Rås Basin, the thickness of the Early Cretaceous section increases dramatically. The Ytreholmen Fault Complex contains a half-graben with reflective northwest-dipping fill that appears to downlap or onlap onto strongly rotated strata below. Seismic quality does not allow for a detailed analysis of the fill of these basins; Triassic and Jurassic strata on the Dønna Terrace are strongly rotated in the fault block at profile $\mathrm{km} c$. 220, indicating that the main phase of faulting, and thus the fill of the allochthonous half-graben in the Ytreholmen Fault zone, may be Early Cretaceous in age. They do, however, appear to be capped by an Early Cretaceous unconformity that separates them from the main part of the overlying Cretaceous succession.

Northwest of the Fles Fault Complex, the extensional detachment fault and rotated allochthon are associated with southeast-dipping to subhorizontal reflector packages in a wedge-shaped supradetachment basin southeast of the Rån Ridge (Fig. 6B, D-F). This assemblage is overlain by a strongly reflective interval that onlaps the southeast-dipping flank of the Rån Ridge, and is assumed to be Early Cretaceous (AlbianAptian?) in age. Stratigraphically higher reflectors in the Cretaceous succession onlap the Rån Ridge towards the northwest.

\section{Transect 5: Central Vøring Basin}

The transect was constructed along the seismic reflection profiles MNR05-7332 and GMNR94-105 (Fig. 7A). The sections show the configuration of structures and basins under the Trøndelag Platform and provide important additional information about the structural setting of the Rån Ridge (e.g., Fig. 7B).

\section{Basement structure}

The top of seismic basement under the Trøndelag Platform is placed at the pronounced double reflector that may represent top of crystalline basement or MidPalaeozoic deposits but which may also represent the top of Late Permian anhydrites drilled in the Helgeland Basin area (Bugge et al., 2002; Osmundsen et al., 2002; Müller et al., 2005). Below this level, there is a diffuse transition from relatively transparent to reflective basement, and a transition in density from $2750 \mathrm{~kg} /$ $\mathrm{m}^{3}$ to $2850-2950 \mathrm{~kg} / \mathrm{m}^{3}$ has been modelled based on potential field data. Under the Trøndelag Platform, the top of seismic basement is displaced continentwards by an array of large normal faults. Some of these faults have large displacements (10 kilometres or more) but appear to terminate in the middle or lower crust. The seismic interpretation and potential field modelling is consistent 
with thinning of the crystalline crust from a thickness of near $30 \mathrm{~km}$ at the coast to $15-22 \mathrm{~km}$ under much of the platform.

The Revfallet Fault Complex constitutes the border to the Dønna Terrace and thus the border between the proximal and necking domains sensu Péron-Pinvidic et al. (2013). Crustal thinning to a thickness of $12-14 \mathrm{~km}$ takes place under the terrace and its northwest margin in the direction of the Rås Basin. The border towards the distal margin comprises the poorly imaged Ytreholmen Fault zone (Blystad et al., 1995), which, as in the previous transect, appears to be associated with extensional rider blocks and a subordinate half-graben. Rotated beds can be interpreted adjacent to this zone at great depth, indicating that the Ytreholmen Fault zone continues northwestwards underneath the Rås Basin. Under parts of the Rås Basin, the crust is thinned to 5 kilometres thickness or less.

The displacement along the upper, most well-imaged parts of the main strand can be constrained to a minimum of $12 \mathrm{~km}$ from the seismic reflection data. However, the potential field model indicates that the main zone of crustal thinning is located under the Ytreholmen Fault zone and it is inferred here that its total displacement is in the order of tens of kilometres. In Fig. $7 \mathrm{D}, \mathrm{E}$, the FFC is interpreted to offset the Ytreholmen Fault zone and thus the outer parts of the necking domain. An implication would be that the Ytreholmen Fault zone originally continued under the Rås Basin and the trailing edge of the Rån Ridge, as suggested above for MNR05-7300. The overall effect of the large-magnitude normal faulting depends somewhat on the interpretation of lithologies at depth.

A valuable observation in this respect is the rise of a marked reflector from c. $9.3 \mathrm{~s}$ to $c .8 .5 \mathrm{~s}$ twt (19 to 15 $\mathrm{km}$ in the depth-converted section) between profile $\mathrm{km}$ 180 and 150 in MNR05-7332 (Fig. 7A, B). The reflector caps a body with a modelled density of $3100 \mathrm{~kg} / \mathrm{m} 3$ and appears to become tectonically excised near the trailing edge of the Rån Ridge. If the underlying body is allowed to represent dense lower crust, for instance an eclogite body (see Mjelde et al., 2012), the crustal thickness would increase from a minimum under the Rås Basin to up to $9 \mathrm{~km}$ under areas west of the FFC (Fig. 7D). The overall setting of the ' $\mathrm{T}$ '-reflector in this area does, however, resemble that of mantle reflectors observed at other margins like the ' $\mathrm{S}$ ' or the HHD reflectors in Iberia (Reston, 1996; Manatschal et al., 2001), the P reflector in the Porcupine Basin (Reston et al., 2001) or the M-reflector in the South Atlantic (Blaich et al., 2010).We tentatively interpret the SE-dipping segment of ' $\mathrm{T}$ ' described above to represent the top of the paleo(Jurassic-Cretaceous) mantle. In such a scenario, the underlying high-density body would likely be composed of altered (e.g., serpentinised, deformed, infiltrated) mantle. Under such an interpretation (Fig. 7E), we consider a strongly thinned and partly dismembered crust northwest of the FFC as likely. Detachment faults that incise the level represented by the SE-dipping ' $\mathrm{T}$ '-segment would represent top mantle detachments ('exhumation faults'). Considering our interpretation of a northwest-dipping, originally horizontal detachment fault at the trailing edge of the Rån Ridge (Fig. 6) and the lack of age-control on the strata in the ridge, we consider complete dismemberment of the crystalline crust as a distinct possibility, (Fig. 7; and Péron-Pinvidic \& Osmundsen, 2016).

Between profile $\mathrm{km} c .50$ and 110, a well-defined reflector separates the core of the Rån Ridge from a deep basin with faulted Cretaceous strata that are possibly, but not necessarily underlain by Jurassic and older sedimentary rocks. The reflector is interpreted as a fault plane, possibly enhanced by dykes. The reflector flattens with depth and at 50-60 km it appears to be incised into the ' $\mathrm{T}$ '-reflector, supporting the interpretation of a listric detachment fault that cuts ' $\mathrm{T}$ '. This would indicate the presence of two generations of 'exhumation-type' faults in the outer Norwegian margin. One is represented by the detachment complex at the trailing edge of the Rån Ridge, the other by the (younger) detachment that bounds the deep outboard Cretaceous basin on the northwest side of Rån. The displacement along this structure is not well constrained, but is likely to be in the order of tens of kilometres. Similar to the previous transect, the FFC is interpreted to cut and displace the major, west-throwing Ytreholmen Fault Complex.

\section{Basin configuration}

To a first order, large parts of the basin configuration resemble that of the previous transect, with extensional allochthon and supradetachment basins related to a major detachment at the trailing edge of the Rån Ridge. A main asset, however, is the detachment fault on the northwestern side of the ridge and its relationship to the hanging wall sedimentary basin. The age of the lower parts of this basin is unknown, and may consist of blocks or an allochthon of pre-Cretaceous rocks (Fig. 7D). Another interpretation may be that Cretaceous rocks rest directly on the detachment to great depth (Fig. 7F), with pre-Cretaceous stratigraphic units tectonically removed from the section. The architecture of the strongly faulted, adjacent Cretaceous basin differs from the preserved and imaged Cretaceous basin at the trailing edge of the Rån ridge. It appears clear that the more outboard basins experienced a phase of faulting not recognised inboard, and that this phase post-dates the faulting that separated the terrace from the distal margin. This is consistent with the previously reported basinward-stepping rifting on the Mid-Norwegian margin (e.g., Lundin \& Doré, 1997; Doré et al., 1999), a phenomenon that is also well documented off e.g., Iberia (Ranero \& Pérez-Gussinyé, 2010; Sutra et al., 2013). Parts of the outer basin imaged in MNR05-7332 can be correlated with stratigraphy 
Transect 5
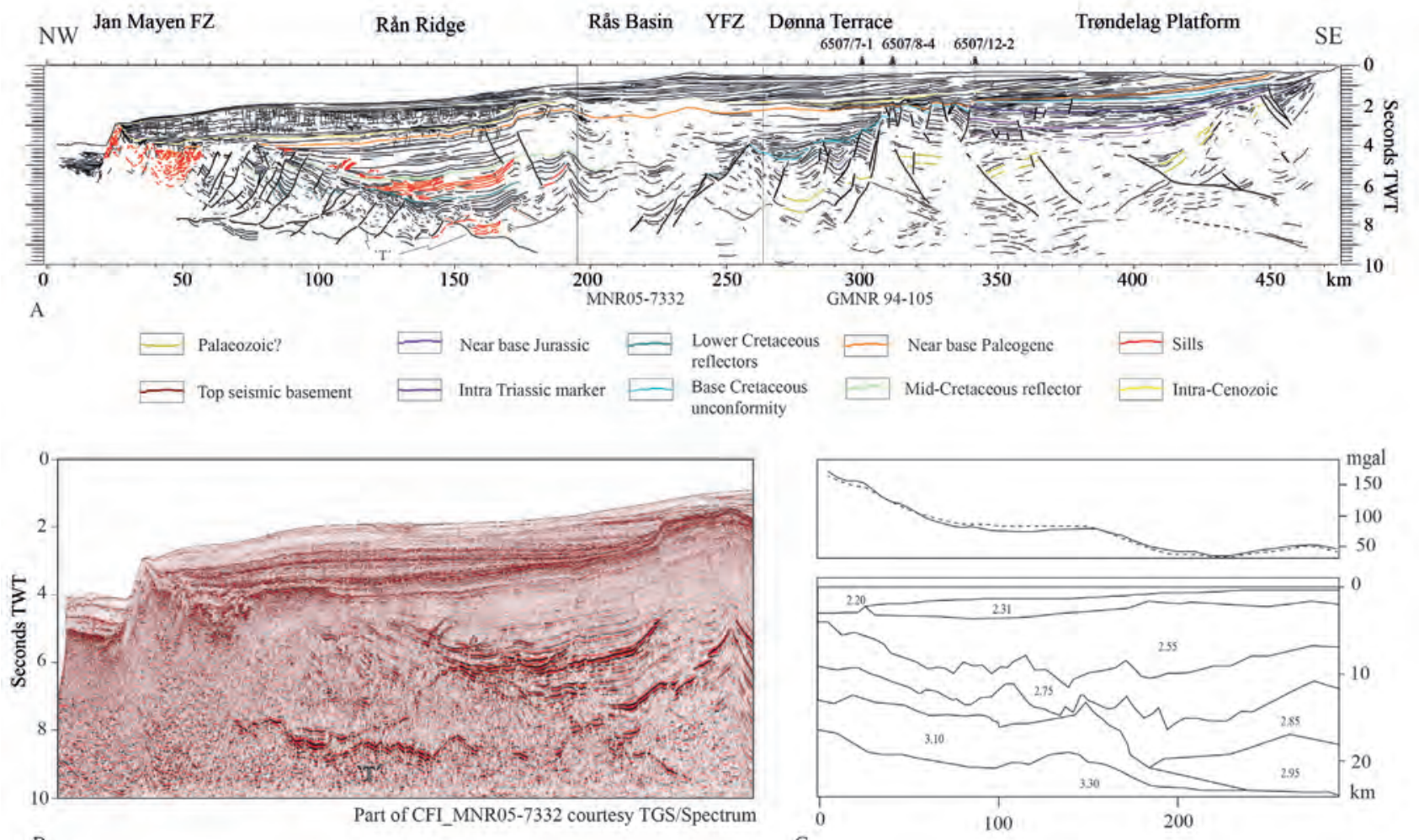

B

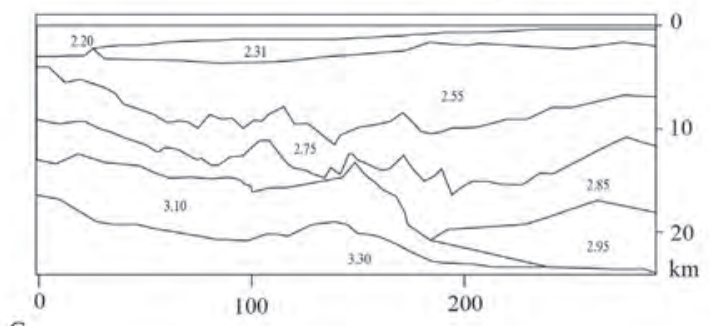

C
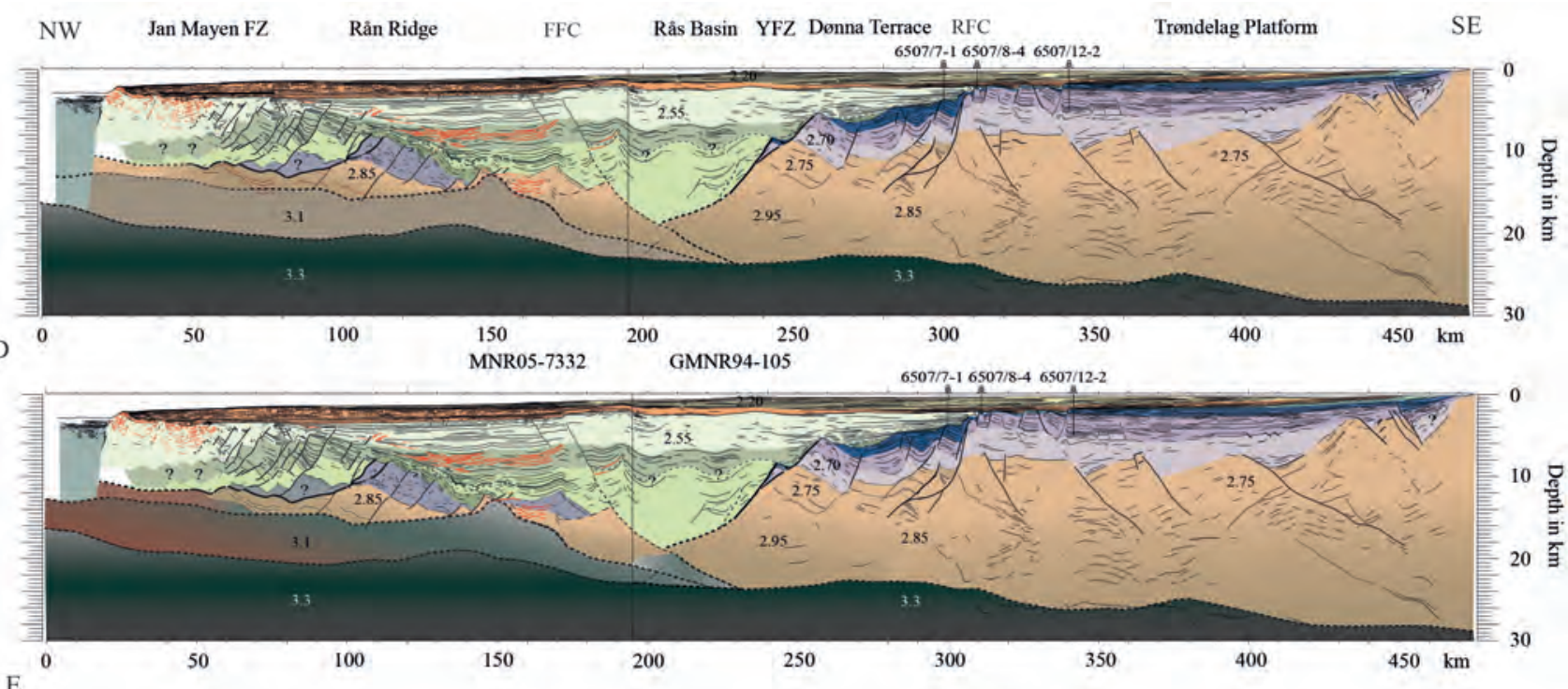

E

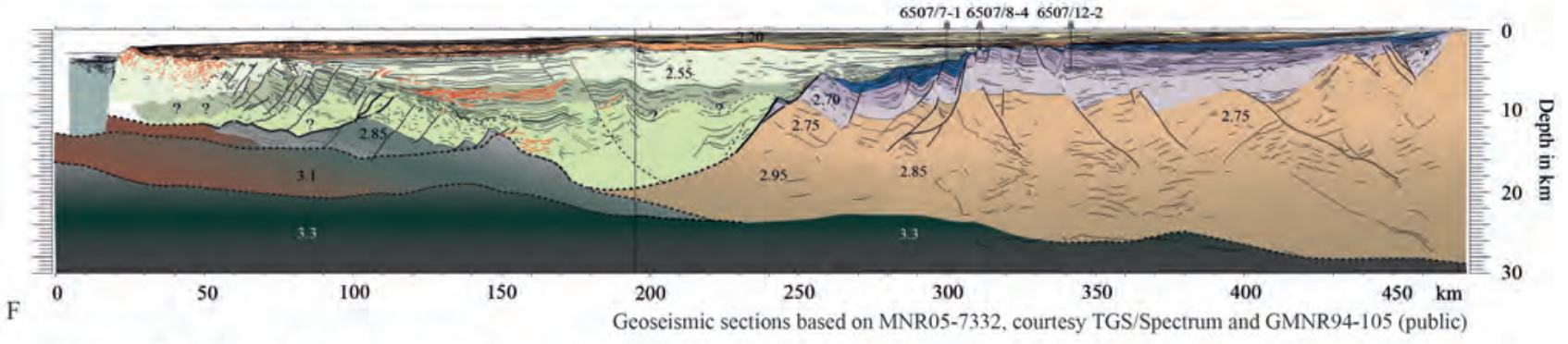

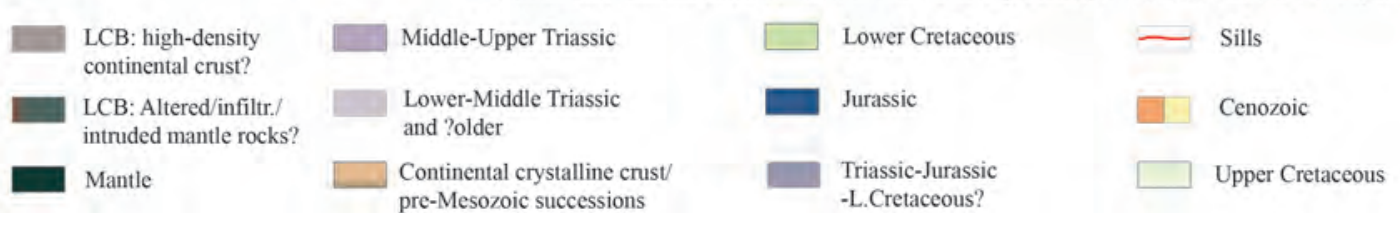


penetrated by the exploration well $6603 / 5-1$ in the south Gjallar Ridge. The well proved the existence of a thick Lower Cretaceous section and that faulting went on well into the Late Cretaceous northwest of the Rån Ridge and in the Gjallar Ridge area, displacing pre-Cretaceous rocks, if present, kilometres down to the northwest in this part of the outer Vøring margin.

The Rån Ridge area presents spectacular assemblages of intrusive igneous rocks, and there is abundant evidence for intrusions following fault planes. In the present transect, note clusters of intrusions at the trailing edge of the Rån Ridge, above and east of the boundary fault to the outer Cretaceous basin, and in the far northwest of the section. The main faults appear to have served as conduits for intrusions during breakup-related magmatic activity.

Figure 7. Transect 5. (A) Two-way time interpretation of composite section constructed from long-offset seismic reflection profiles MNR05-7332 and GMNR94-105. The proximal margin domain is dominated by deep-seated, pre-Late Triassic basins containing sediments deposited adjacent to continent-facing faults. This configuration is abruptly truncated by the faults in the necking domain, which are seaward-dipping in our interpretation. The Ytreholmen Fault zone (YFZ) is not very well imaged but small, rotated fault blocks can be identified at different depths along the basin flank. Inset rectangle marks location of seismic image in (B). (B) Seismic detail showing trailing edge of the Rån Ridge. Note the southeastward-dipping segment of the ' $T$ '-reflector between c. 8 and $10 \mathrm{~s} \mathrm{twt} \mathrm{at} \mathrm{profile} \mathrm{km}$ c. 150-180. The reflector appears as having been cut and displaced by faults and its interpretation as the top of lower crust or mantle is critical for this part of the Vøring Basin. The basement-cored parts of the Ran Ridge are juxtaposed with a deep Cretaceous basin across a northwestward-dipping reflector interpreted as a main detachment breakaway. Note also the occurrence of clusters of sills in the vicinity of important fault zones, indicating that the latter were important conduits for magma. (C) Density model constructed along line MNR05-7332 based on published seismic refraction data and potential field modelling. (D-F) Alternative interpretation scenarios for transect 5. In (D), rocks with densities between 3100 and $2850 \mathrm{~kg} / \mathrm{m}^{3}$ are considered to represent continental crystalline crust. In this scenario, the Vøring Basin is floored by c. 5-10 km of continental crust between the Ytreholmen Fault zone and the Jan Mayen Fracture Zone, and the Ran Ridge is cored by continental crust and capped by pre-Cretaceous rocks. The southeast-dipping segment of the ' $T$ ' reflector between $\mathrm{km} 150$ and 180 would be an intracrustal reflector in this interpretation. In (E), the body with density $3.1 \mathrm{~kg} / \mathrm{dm}^{3}$ is interpreted to represent partly serpentinised mantle, probably densely intruded by magmatic products, and the southeast-dipping segment of ' $T$ ' represents the top of this body. We have tentatively included two, smaller, serpentinised mantle bodies with lower densities in the outer margin and under the central parts of the Rås Basin, respectively. The outer of these would be capped by the ' $T$ '-reflector and the other is hypothetical but consistent with the Fles Fault Complex (FFC) cutting and displacing the outer parts of the necking domain (see text). In $(F)$, all rocks in the outer margin with densities of $2850 \mathrm{~kg} / \mathrm{m}^{3}$ or more represent mantle rocks. In this interpretation, all pre-Cretaceous rocks were stripped from the section through the unroofing of 2 or 3 generations of detachment faults (see Péron-Pinvidic et al., 2016). Abbreviation: RFC - Revfallet Fault Complex.

\section{Transect 6: North-central Vøring-Basin}

This transect was constructed based on the seismic reflection profile MNR05-7397 (Fig. 8A, B). The E-W acquisition trend has a low angle with the NE-SW orientation of the central and northern Vøring Basin and thus the section is strongly oblique to the structural grain. Seismic quality is good or very good in the southeastern and northwestern parts of the section, but poor at depth in the densely intruded Vigrid Syncline. The highlight of the section is the imaging of strongly faulted stratigraphy in the southern Gjallar Ridge (Fig. 8B), which was penetrated by the exploration well 6603/5-1, confirming a thick Lower Cretaceous succession (see below). Other features that are well imaged in the seismic section are reverse faults and folds on the southeast flank of the Utgard High. The area of the Vigrid Syncline is well imaged to a depth of a few kilometres but sill intrusions severely complicate interpretation at depth. Thus, our interpretations of basement or pre-Cretaceous rocks in the Vigrid Syncline are strongly speculative.

\section{Basement structure}

The top of basement is neither well imaged nor constrained by the seismic data. Southeast of the Revfallet Fault Complex, the top of basement was therefore constructed based on reflectors that occur below a largely transparent succession of assumed sedimentary rocks with densities in the order of 2550 $\mathrm{kg} / \mathrm{m}^{3}$ according to the gravity modelling. Low-magnetic rocks in the seismic basement with densities of c. 2700 $\mathrm{kg} / \mathrm{m}^{3}$ may also possibly represent Late Palaeozoic sedimentary rocks or, alternatively, metasedimentary rocks in Caledonian nappes. The Revfallet Fault Complex is not well imaged at depth. It does, however, coincide with a modelled strong reduction in crustal thickness and with the juxtaposition of Triassic with Cretaceous strata along the southeast border of the Træna Basin. On the northwest side of the Træna Basin, the southeastdipping continuation of the FFC borders the Utgard High. The displacement is not well constrained, but may be in the order of several kilometres, depending on the location of the poorly constrained top of basement inside the high. A suite of reverse faults, interpreted to represent late reactivation of the $\mathrm{FFC}$, is interpreted to core an anticline along the southeastern flank of the High.

In Fig. 8D, depth to basement in the Utgard High is based entirely on the potential field modelling. Northwest of the Utgard High, the suggested top of basement follows the $6+\mathrm{km} / \mathrm{s}$ velocities obtained from the OBS and gravity modelling, as well as the base of a strongly reflective layer in the seismic section. In Fig. 8E, F, we explore the possibilities of replacing parts of the basement with sedimentary rocks inside and northwest of the Utgard High. Inside the high, we tentatively place the top of 
Transect 6
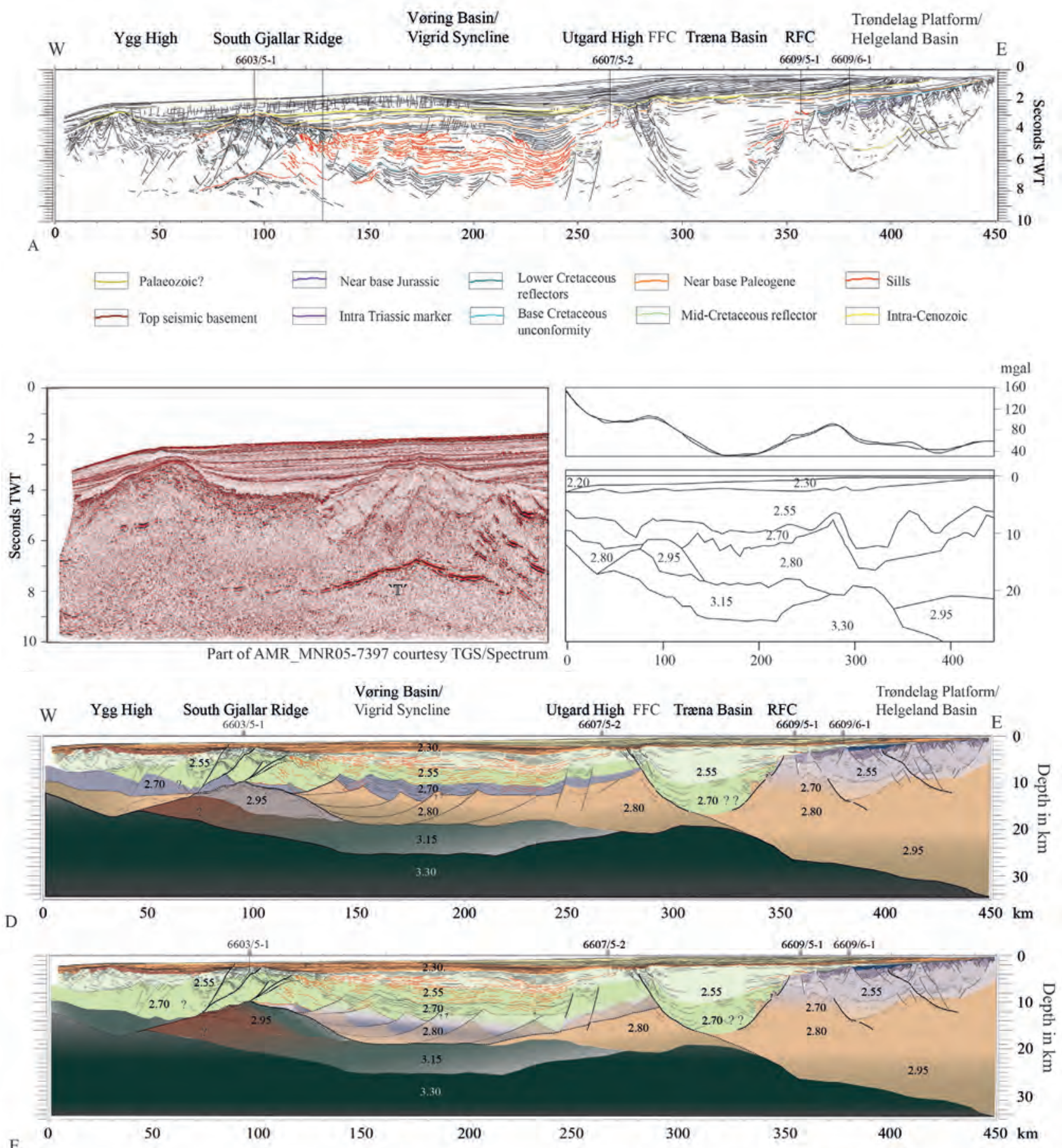

E

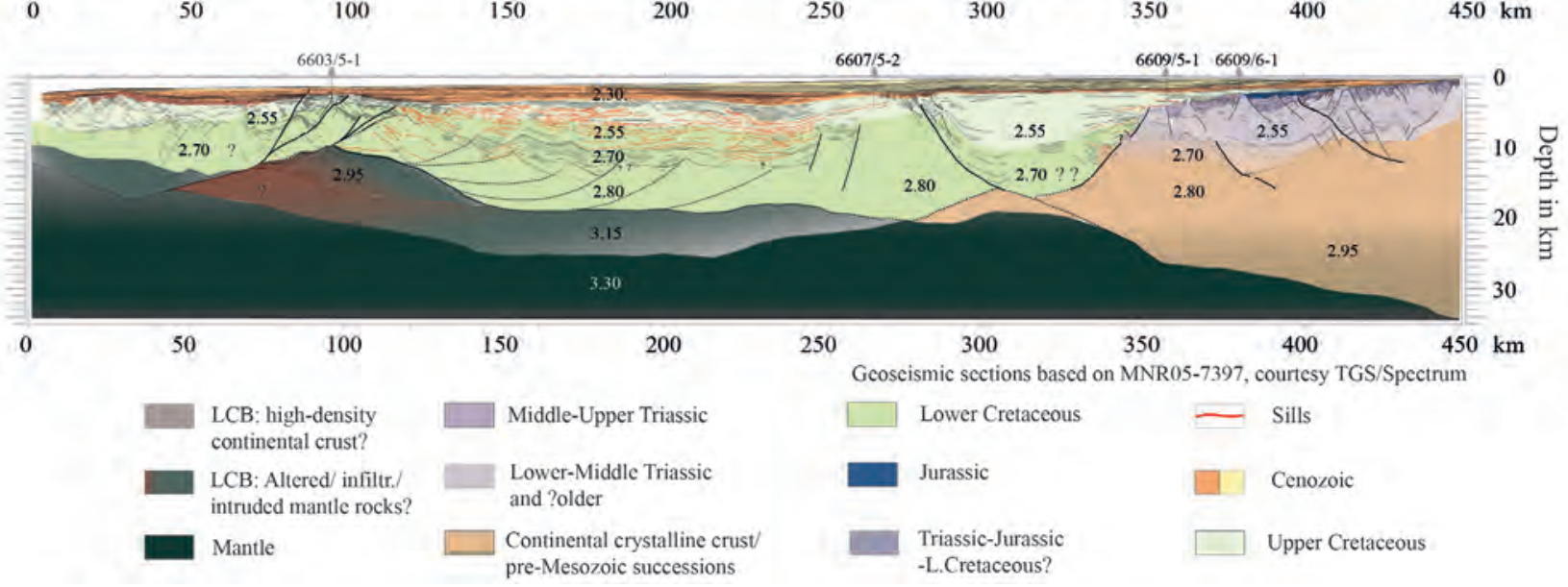


crystalline basement along a northwest-sloping reflector band that occurs between 7 and 8 seconds twt at profile $\mathrm{km}$ 270-290.

In the northwestern parts of the section, the top of basement is interpreted to be represented by the convexupward ' $\mathrm{T}$ '-reflector. The ' $\mathrm{T}$ '-reflector is underlain by a body with a modelled density of $2.95 \mathrm{~g} / \mathrm{cm}^{2}$, consistent with lower crust (Fig. 8D) or serpentinised mantle (Fig. $8 \mathrm{E}, \mathrm{F})$. The nature of the basement under the Gjallar Ridge has been debated at length (e.g., Gernigon et al., 2004), but in our view, the suggestion of Ren et al. (1998) that it represents an extensional detachment on top of serpentinised mantle rocks may be a viable scenario considering our interpretations of the previous transects in this paper. This interpretation would require that the density of the mantle rocks was reduced to the modelled value of $c .2950 \mathrm{~kg} / \mathrm{m} 3$ in the culmination that underlies

Figure 8. Transect 6. (A) Two-way time interpretation based on long-offset seismic reflection profile MNR05-7397. The proximal margin domain hosts deep basins of Jurassic, Triassic and likely Permian age (e.g., Bugge et al., 2002). The top of basement is poorly constrained from the seismic reflection data. The main breakaway for the distal margin domain in this area is the Revfallet Fault Complex, which juxtaposes the proximal margin with the deep Trona Basin. Northwest of the Trana Basin, the southeastern flank of the Utgard High is defined by the northern continuation of the Fles Fault Complex, which shows evidence for reactivation during Tertiary contraction. The Vigrid Syncline is densely intruded by sills and preCretaceous rocks are not well imaged. Inset rectangle shows location of seimic image in (B). (B) Seismic inset showing details of the south Gjallar Ridge and the underlying, convex-upwards ' $T$ '-reflector. The stratigraphy of the south Gjallar Ridge is constrained by exploration well 6603/5-1 which terminated in Albian-Aptian rocks. The Ygg High is not well imaged at depth but southeast-dipping reflectors may indicate fault rotation of sedimentary rocks below Cenozoic volcanic rocks. (C) Density model constructed along transect 6, based on published refraction models and potential field data. (D-F) Alternative interpretation scenarios for the north-central Vøring Basin transect. In (D), rocks with density between 2.70 and $3.3 \mathrm{~g} / \mathrm{cm} 3$ are considered to represent crystalline continental crust. In this scenario, this part of the Vøring Basin is floored by a 5-10 km-thick layer of continental crust.with a crustal thickness $>12 \mathrm{~km}$ in the Utgard High. In (E) and $(F)$, we have moved the top of basement progressively downwards, which would require sediment densities of c. 2.8 in the lowermost parts of the basin. This may be compensated for by a thinner LCB (not shown here). Considering the vast amounts of igneous rocks in the section, we consider it likely that the LCB contains a component of intruded igneous material. Abbreviations: FFC - Fles Fault Complex, RFC - Revfallet Fault Complex. the ridge, an assumption that is not unrealistic. The density of sill intrusions above the southeast flank of the culmination may indicate the presence of underplated magmatic rocks in the body described by the convexupward ' $\mathrm{T}$ '-reflector. The detachment representing ' $\mathrm{T}$ ' may also have been intruded by sills that enhanced its seismic reflection amplitude. The northwest-dipping faults that cut Cretaceous strata in the ridge have offsets of up to the order of c. 3-4 km based on the reflective Albian-Aptian interval that was penetrated by $6603 / 5-1$ (Fig. 8). At depth, the faults cut the ' $\mathrm{T}$ '-reflector, and tentatively, the northwestern flank of the culmination outlined by ' $T$ ' may represent a second-generation detachment fault. This secondary detachment is associated with a breakaway area at profile $\mathrm{km} c .110-120$, characterised by kilometre-scale normal displacements of the Aptian marker and a dense network of sill intrusions.

\section{Basin configuration}

The Late Palaeozoic (?) to Triassic and Jurassic basin on the northern Trøndelag Platform is characterised by westward dips of bedding and an apparent westwards thickening along the line of section. This basin is abruptly cut by the northwest-dipping Revfallet Fault Complex and juxtaposed against the deep Cretaceous Træna Basin. The Træna Basin has an overall synclinal geometry, with bedding being rotated to steep dips and folded along the reactivated FFC. Similar to the Rås Basin farther south, the Træna Basin is poorly imaged at depth and the top of basement cannot be confidently defined based on the seismic reflection data. The potential field modelling suggests that the top of crystalline basement is located at between $c .13$ and $17 \mathrm{~km}$ depth. Inside of, and to the west of the Utgard High, basin depth is equally difficult to assess from the seismic reflection data. Between the Utgard High and the south Gjallar Ridge, the basin is densely intruded by sills, which hamper signal penetration and lower the imaging quality significantly. Based on the potential field modelling, the top of a body with density of 2800 $\mathrm{kg} / \mathrm{m}^{3}$ occurs at between 10 and $13 \mathrm{~km}$ depth west of the Utgard High. In our most conservative scenario (Fig. 8D), this corresponds to the depth of the Late Palaeozoic-Mesozoic basin. In alternative scenarios, we speculate that the basin may be even deeper (Fig. 8E, F). This would require high densities around $2800 \mathrm{~kg} / \mathrm{m}^{3}$ for the deepest parts of the stratigraphy according to the potential field model. Published refraction models have however, indicated sediments with densities of $2700-2800 \mathrm{~kg} / \mathrm{m}^{3}$ for parts of the margin (e.g., Mjelde et al., 2009a), so such a scenario is not necessarily in conflict with existing geophysical models. In the south Gjallar Ridge, a marked stratigraphic boundary was proven by the exploration well 6603/5-1 to represent Aptian strata. Terminated at 5000 metres depth, the well proved the existence of a thick Cretaceous succession in 
the South Gjallar Ridge (www.npd.no/fact pages/wells). The southeastwards descent of this stratigraphy to great depths in the Vigrid Syncline indicates a deep location of the ' $\mathrm{BCU}$ ', probably below $10 \mathrm{~km}$ or more in the deepest parts of the basin.

Between profile $\mathrm{km} 0$ and $c .130$, the Cretaceous basin is densely faulted and the correlation of stratigraphic markers is difficult. In our most conservative scenario (Fig. 8D), we consider that pre-Cretaceous sedimentary rocks may exist at depth underneath a thick Cretaceous succession in the South Gjallar Ridge, as a continuation of a possible pre-Cretaceous basin at depth in the Vigrid Syncline. The uncertainty with respect to this interpretation is substantiated by the observation of a secondary detachment associated with the Gjallar Ridge. Alternatively, a deep Cretaceous basin may rest directly on basement underneath the south Gjallar Ridge and the Ygg High (Fig. 8E, F). The Ygg High is infiltrated by intrusions, but southeastward-dipping reflectors may indicate the presence of faulted and rotated sedimentary rocks underneath the magmatic rocks.

\section{Discussion}

\section{Geological uncertainties in the correlation of geophysical datasets}

In the construction of geoseismic transects, we have interpreted seismic reflection data down to a certain confidence level, below which refraction-based crustal models and potential field modelling have been used to complete the transect at depth. For some of the sections in the present study, it became clear that the interpretations of lithological bodies modelled from refraction and potential field data would be at odds with a number of observations in the long-offset seismic reflection data. In addition to the commonly favoured interpretation where a modelled geobody is translated directly into a specific rock type, we adapted a different interpretation protocol where a given set of geophysical parameters may be translated into different lithologies, depending on the structural configuration interpreted from the seismic reflection data.

Since the Norwegian margin shows clear evidence for hyperextension where the crust is thinned to less than c. $10 \mathrm{~km}$ thickness over considerable areas (e.g., Mjelde et al., 2009a, b), problems arise with the interpretation of lithologies at depth in the distal margin.

Serpentinisation of mantle rocks is commonly thought to occur when the crust is strongly thinned and brittle faults cut it entirely, providing channelways for water to reach the upper mantle and allow hydration of peridotite (Pérez-Gussinyé \& Reston, 2001; Reston,
2009). Pervasively serpentinised exhumed mantle has been proven so far only for the Iberia-Newfoundland conjugate system, but a number of margins show similar structural configurations and the possibility for mantle serpentinisation should be considered (e.g., Reston, 2009; Péron-Pinvidic et al., 2013). A problem is that where serpentinisation of mantle is theoretically possible due to extreme crustal thinning, the overlap of physical properties for crystalline crustal rocks and altered mantle rocks hampers the interpretation of lithological bodies.

Density values for serpentinites range between 2340 and $3250 \mathrm{~kg} / \mathrm{m}^{3}$ according to a compilation by Dietze \& Kontny (2011). In a study of abyssal serpentinites obtained from ODP drill sites, Oufi et al. (2002) reported densities in the range of $2460-2990 \mathrm{~kg} / \mathrm{m}^{3}$, with $90 \%$ of the recorded densities in the range $2650-2850 \mathrm{~kg} /$ $\mathrm{m}^{3}$. Magnetic susceptibilities range over several orders of magnitude, from $0.04-192.7^{\star} 10^{-3}$ SI according to Dietze \& Kontny (2011). Oufi et al. (2002) reported susceptibilities ranging from 0.002 to 0.153 SI in their study. Compared to the values for continental crystalline rocks that are well constrained for the inner parts of the Norwegian margin (Ebbing et al., 2009), the overlap is very significant.

Thus, in our view, an important confidence boundary should be placed at the taper break of Osmundsen \& Redfield (2011), where the tapered crystalline crust is juxtaposed with the strongly thinned and tectonically deformed rocks of the distal margin. Outboard of the taper break, geophysically defined bodies with densities and magnetic properties similar to those of the continental crust could also be composed of serpentinised mantle, as shown for the IberianNewfoundland margin pair (i.e., Dean et al., 2000). In such a scenario, the correlation of geophysically defined bodies across the taper break may lead to misinterpretation.

$\mathrm{Vp} / \mathrm{Vs}$ ratios modelled from seismic refraction data can be diagnostic in separating lithologies at depth, but the method is vulnerable to the presence of fluids as well as tectonic fabrics (e.g., Reynard et al., 2010). Both would be expected to be abundant in the lower crust and upper mantle at highly extended rifted margins (e.g., PérezGussinyé \& Reston, 2001). Furthermore, Vp/Vs ratios of serpentinite show large variations depending on mineralogy (e.g., chrysotile vs. antigorite serpentines; Guillot et al., 2015). In our opinion, serpentinisation of mantle rocks and exhumation of altered mantle in windows under the most highly extended areas are realistic options for the Norwegian margin (Osmundsen \& Ebbing, 2008; Lundin \& Doré, 2011; Péron-Pinvidic et al., 2013).

Similar problems may arise where the density and magnetic properties of deep-seated sedimentary rocks overlap with those of low-magnetic metasediments 
in the metamorphic basement (Ebbing et al., 2009). Important discriminating factors are rock density and seismic velocity, but for sediments buried by 10-15 $\mathrm{km}$ or more this becomes ambiguous. The density of sedimentary rocks increases by mechanical compaction and temperature-controlled diagenetic processes during burial, and may even reach low-grade metamorphic conditions. Rocks exhumed rapidly in the footwalls of extensional detachment faults can contain residual heat that, in combination with shear heating, may lead to significantly elevated temperatures in the overlying basin (Souche et al., 2012). If successively deeper and hotter parts of the deep crust and mantle were exhumed seawards during seaward-stepping faulting, such processes may have been occurring increasingly towards the line of breakup from the Early Cretaceous onwards.

\section{Summary: the Møre margin}

The Møre margin presents a very sharply tapered necking domain that consists largely of fault planes eroded to various degrees (Figs. $3 \& 4$ ). The geometry changes laterally along the Møre margin as well as between the Møre and Vøring margins (Fig. 9), suggesting lateral variations in the configuration of large-magnitude faults. An important difference between the southern and northeastern parts of the inner parts of the distal Møre margin appears to be the lack of large, rotated fault blocks in the south, whereas a well-defined domain of tilted blocks is well imaged in the northeast (Figs. $3 \& 4$ ). The thin layer with modelled crustal densities of $2.95 \mathrm{~g} /$ $\mathrm{cm}^{3}$ underlying the deepest parts of the south Møre Basin may well represent serpentinised mantle. We favour a scenario where mantle may have become exhumed some $100-120 \mathrm{~km}$ offshore, but recognise the ambiguity which is reflected by the different scenarios for each profile. Under this interpretation, the south Vigra High would be an allochthonous block resting on a mantle detachment. This configuration would be structurally similar to the well constrained (ODP drilled) geometries observed in the Southern Iberia Abyssal Plain of the Iberia margin. The south Vigra High observed on the GMNR 102R (transect 1) could correspond to the 1069 crustal allochthon observed on the Iberian LG12 profile, and the Vigra High observed farther north on the GMNR 103 (transect 2) could correspond to the northern extent of the 1069 allochthon as a standard tilted block on the CAM144 profile (see Figs. 10 \& 11; Péron-Pinvidic et al., 2007, fig. 6).

In the northeastern Møre Basin (Fig. 4), the tilt-block array that includes the Vigra High represents a hyperextended or 'coupled' subdomain, where some of the half-graben bounding faults probably extended down into the mantle, but where the tilted blocks were likely cored by crystalline crust. The major breakaway that borders the Vigra High soles into a large-magnitude detachment fault that rises towards the breakup line. Overlying the detachment are rotated fault blocks. The fault blocks may contain sedimentary rocks to considerable depth, perhaps down to the basal detachment fault (Fig. 4E, F). The detachment rising towards the Faeroe-Shetland Escarpment is not imaged in the GMNR94-102 profile from the south Møre Basin, but a similar structure may possibly exist there, based on modelled density boundaries that appear to rise towards the margin and on the apparent lack of large, basement-cored, rotated fault blocks outboard of the south Vigra High. Alternatively, the most fundamental detachment may dip southeastwards in the south Møre Basin, leaving the southern parts of the Møre margin in an 'upper plate' position (e.g., Torske \& Prestvik, 1991; Péron-Pinvidic et al., 2016). The distinction cannot be made based on the present data, but such a scenario would require a change in structural style and thus a transfer or accommodation zone between our southern and northeastern Møre transects. Such a lineament may be indicated in the potential field data, in particular in the magnetics, between the Gnausen and Gossa highs. Independent of the polarity of the proposed main detachment, a transfer structure may be located there, explaining in part the difference in structural style (Fig. 9) between the southern and northeastern Møre transects.

\section{The Vøring margin}

For the Vøring margin, recent long-offset seismic reflection data together with the older GMNR94 survey provide tantalising glimpses of the structural configuration under the deep distal margin. In the proximal parts of the south Vøring margin, the Halten Terrace, as well as rotated fault blocks in the inner distal margin, is underlain by well-defined reflector bands interpreted to represent reflective lower crust (Fig. 5; Osmundsen \& Ebbing, 2008). In our interpretation, a major breakaway on the northwest flank of the Slettringen ridge, passes into a subhorizontal detachment fault with displacement in the order of tens of kilometres in the less well-imaged area towards the Jan Mayen Fracture Zone (e.g., Osmundsen et al., 2002; Osmundsen \& Ebbing, 2008). Our interpretation of the detachment flooring a deep outboard sedimentary basin (Fig. 5) contrasts to that of Nirrengarten et al. (2014), who preferred to interpret this interval as continental crystalline crust. In our interpretation, southeastward-rotated reflectors in this interval, imaged c. $30 \mathrm{~km}$ northwest of the ridge, probably represent preCretaceous or Cretaceous sedimentary rocks. A pertinent question is whether mantle rocks became unroofed and exhumed in the footwall of this detachment. Based on analysis of modelled Vp/Vs ratios, Mjelde et al. (2002) did not exclude the possibility of serpentinisation of mantle under the central and southern Vøring Basin, albeit their favoured interpretation was one of crustal rocks and intrusions. Comparing the morphology of this system with that of the Iberian margin, where mantle rocks did 

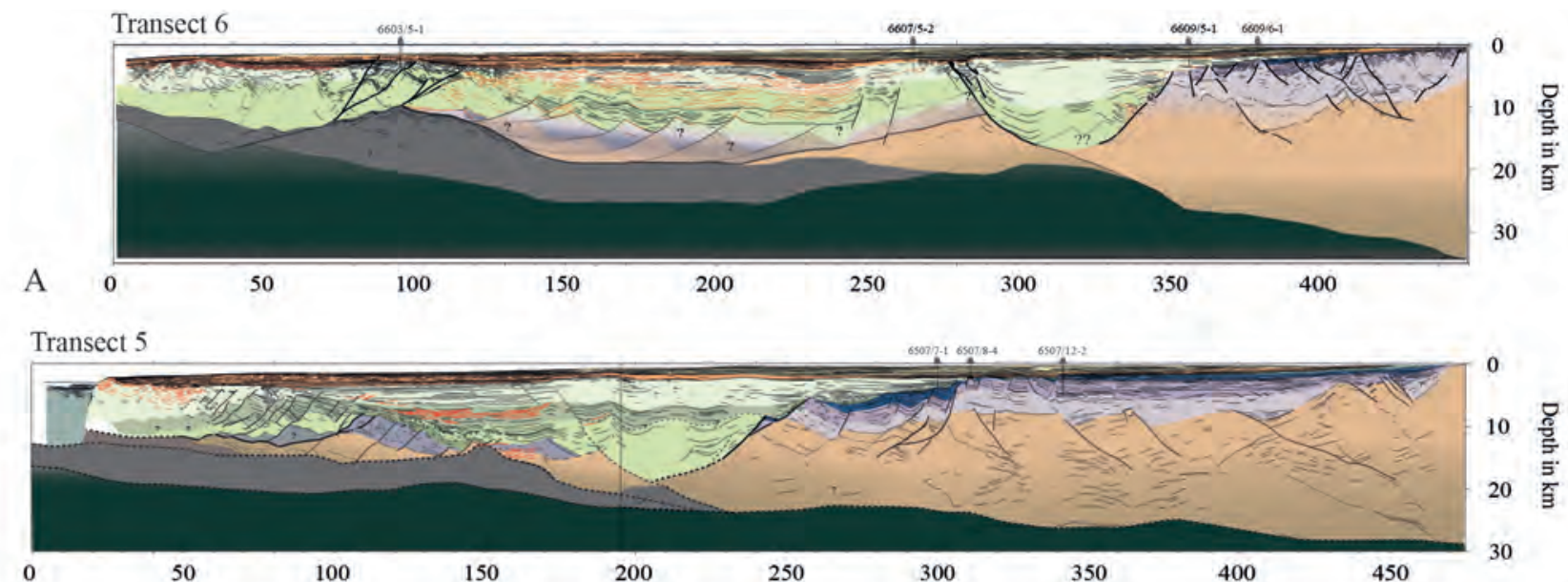

B

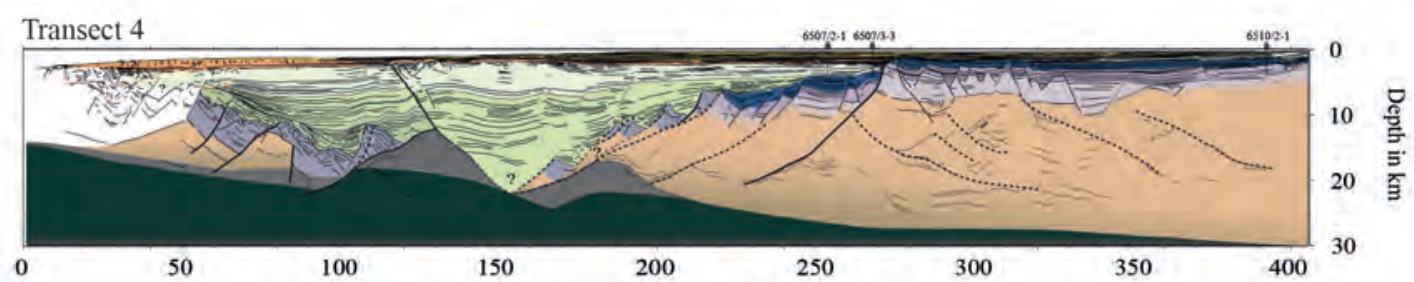

C

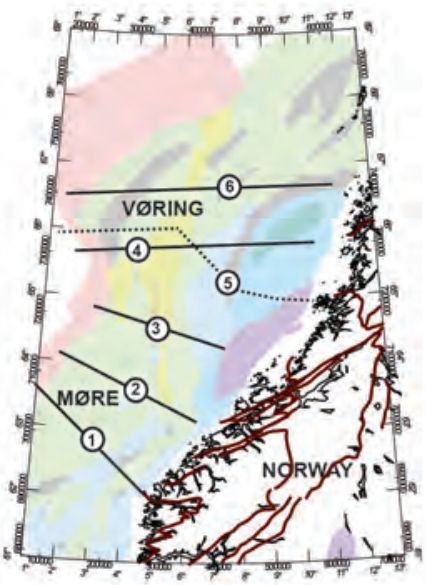

Transect 3
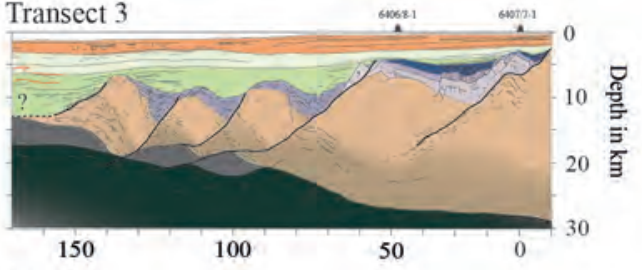

D

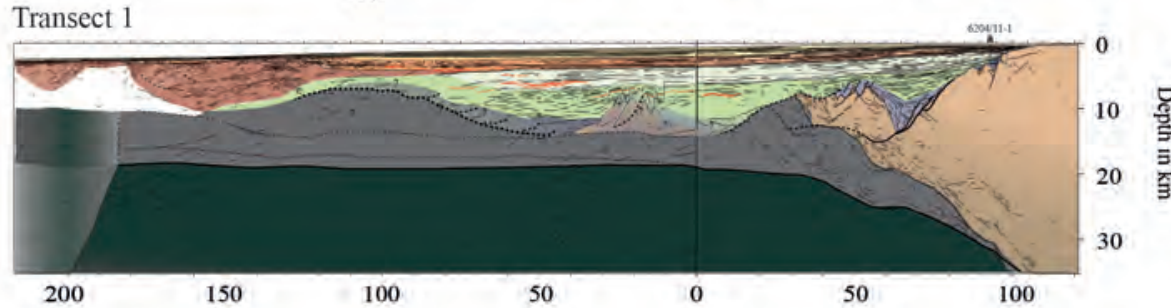

F

Continental crystalline crust/pre-Mesozoic

Altered mantle or highdensity continental crust

Mantle rocks
Triassic-Jurassic

-L.Cretaceous?

Middle-Upper Triassic

Lower-Middle Triassic and ?older

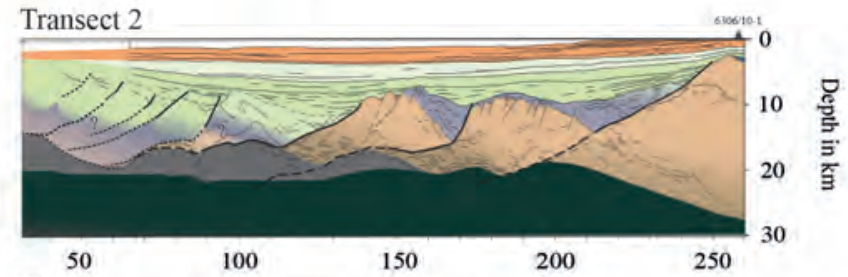

E

Figure 9. Generalised versions of the 6 geoseismic transects presented in this paper plotted together in the same scale to emphasise architectural variations along the Mid-Norwegian rifted margin. Note sharply tapered crystalline crust in the Møre margin and more gently tapered crust in the Vøring margin. Extensional detachments are interpreted in the area of the Rån and Gjallar ridges (transects (A, B and C)) and blockfaulted hyperextended parts of the inner distal margin in transects ( $D$ and E). The Fles Fault Complex (FFC) is interpreted here to have cut and displaced the seaward-dipping arrays of normal faults and detachments, having a major impact on the architecture of the Rås and Trona basins. 
become exhumed under flat-lying detachment faults in the distal margin (e.g., Figs. 10 \& 11; Reston, 1996; Manatschal et al., 2001), and the above uncertainties related to $\mathrm{Vp} / \mathrm{Vs}$ analysis, we rather favour an interpretation of likely mantle exhumation (cf., Lundin \& Doré, 2011). In this case (Fig. 5E) the northwestern flank of the Slettringen Ridge would constitute the breakaway of an 'exhumation fault' in the terminology of Manatschal (2004), or at least the breakaway for a detachment where unroofing went almost to completion.

Farther north, the major, low-angle detachment fault interpreted between the trailing edge of the Rån Ridge and the Fles Fault Complex (FFC) accommodated tens of kilometres of displacement. The orientation of bedding in the Lower Cretaceous strata above the fault shows that it occupied a subhorizontal position shortly after its main phase of activity, which makes it another strong and very well-imaged candidate for an unroofed distal detachment or exhumation fault. In this area, the hyperextended subdomain of large, tilted fault blocks in the inner distal margin appears to be missing, in such a way that the Dønna terrace is juxtaposed directly with the deepest parts of the distal margin. We suggest that the above detachment was related to the seaward-dipping system of Late Jurassic-Early Cretaceous domain-boundary
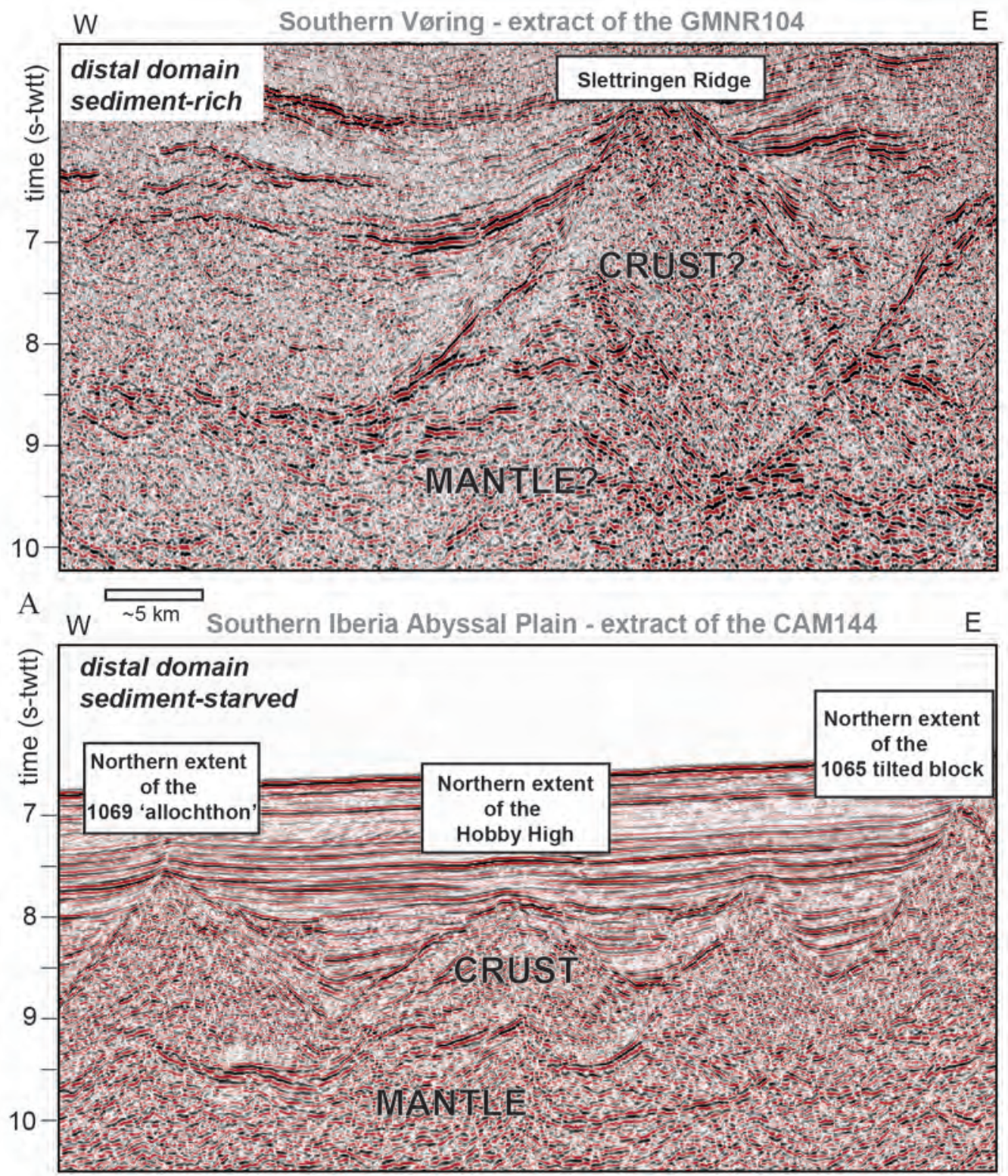

B

Figure 10. Comparison of seismic images of block-faulted, hyperextended crust from the distal Norwegian margin in the Vøring Basin (A) and from the southern Iberia abyssal plain (B). Note deep reflection bands along the crust-mantle boundary and well-imaged faults that truncate this reflective interval. Segments of the reflective bands appear as rotated between the faults. 


\section{VøRING-MøRE} MARGIN

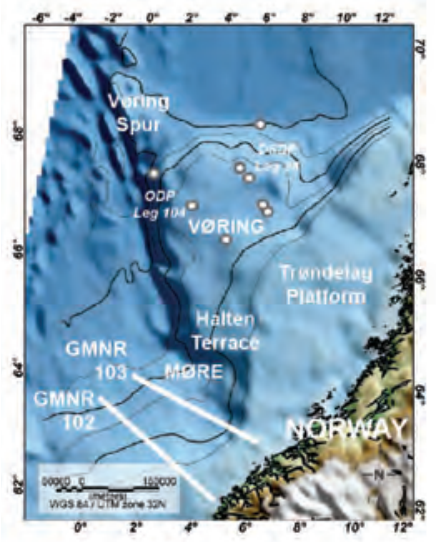

\section{IBERIA MARGIN}

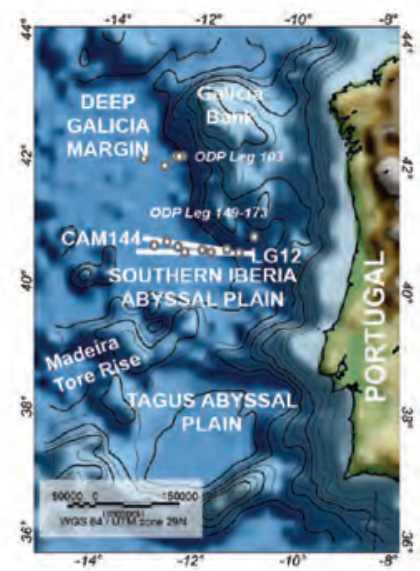

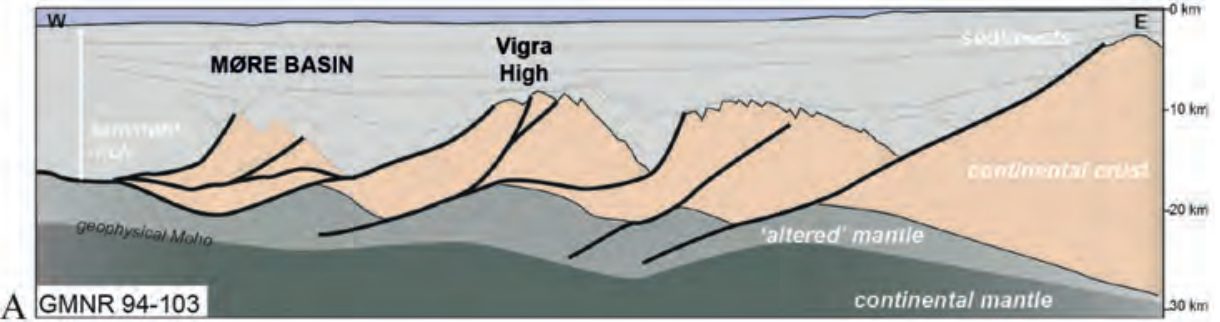

A GMNR 94-103 continental mantle
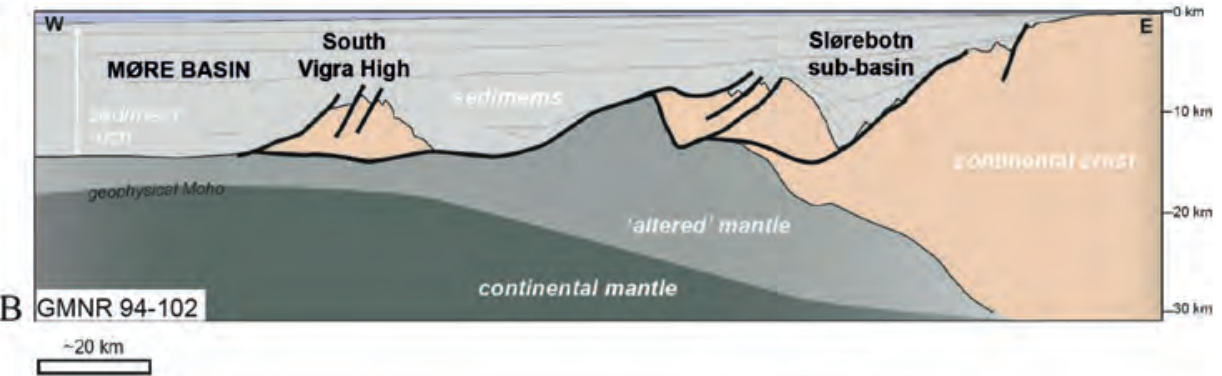

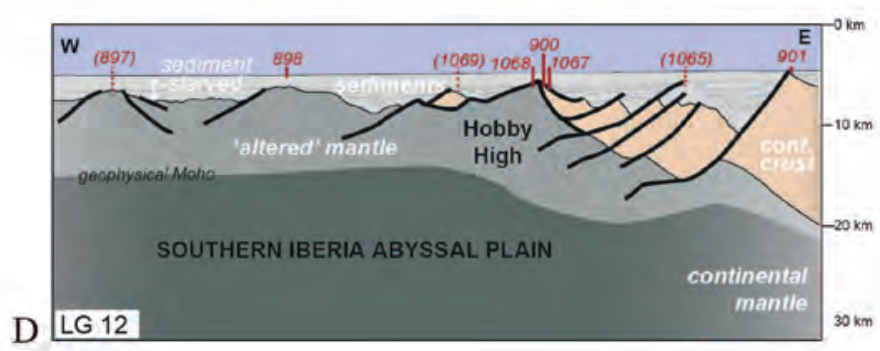

Figure 11. Comparison between depth-converted interpretations of the (A) Lusigal (LG) 12 and (B) CAM 144 sections from the Iberian margin with depth-converted interpretations of (C) GMNR94-102 and (D) GMNR94-103 (most highly extended scenarios for transects 1 and 2) from the Møre Basin. Albeit the presence of exhumed mantle underneath fault blocks and in tectonic windows has not been proven by drilling at the Mid-Norwegian margin, the similarities in structural style and morphology, together with the extreme crustal thinning shown by refraction data and potential field modelling, indicate that such exhumation is likely to have occurred.

faults, and that it may have been continuous with both the Ytreholmen Fault Complex and the detachment northwest of the Slettringen Ridge. In this case, the Rås Basin may have been initiated on a major listric detachment with a total displacement in the order of $100 \mathrm{~km}$. Northwest of the Rås Basin, the well-imaged part of the detachment provided a fundamental, tectonic boundary for the Rån Ridge, which, correspondingly, played the part of a large extensional allochthon through parts of the Early Cretaceous.

The Rån allochthon became bound in the northwest by another, outer detachment, which floors the deep, densely faulted, outboard Cretaceous basin which, in turn, correlates directly with parts of the Cretaceous succession in the south Gjallar Ridge. The displacement along the outer detachment, however, is not well constrained, and below the well-imaged Cretaceous succession the hanging wall basin may contain more Cretaceous rocks or, alternatively, a deep-seated, small allochthon with pre-Cretaceous sediments and/or crystalline basement (Figs. $7 \& 8$ ). The outer detachment cuts the ' $\mathrm{T}$ ' reflector, (Fig. 7) and in the south Gjallar Ridge, a similar situation appears to be the case for large faults that cut the Cretaceous succession (Péron-Pinvidic \& Osmundsen, 2016). Depending on the chosen scenario, the ' $\mathrm{T}$ '-reflector may represent the top of lower crustal rocks, altered mantle or an underplate. Considering the above scenarios, we favour an interpretation of parts of ' $\mathrm{T}$ ' as the Jurassic-Cretaceous crust-mantle boundary, as 
early suggested by Ren et al. (1998) for the Gjallar Ridge. The successive incision of progressively deeper crustal levels and possibly upper mantle by major detachment faults in the distal margin, and the truncation even of this system by the outer detachments, makes it difficult to envisage that significant thicknesses of crystalline crust were preserved northwest of the Rån Ridge.

The continent-dipping Fles Fault Complex (FFC) cut and displaced the major detachment southeast of the Rån Ridge. We suggest that the FFC cut the most distal parts of the Ytrehomen Fault Complex and thus the outer parts of the necking domain or, alternatively, the innermost parts of the distal margin. This is substantiated by the northwestward-rising segment of the ' $\mathrm{T}$ '-reflector observed in MNR05-7332, interpreted tentatively to represent a crust-mantle boundary. It follows from this interpretation that the Ytreholmen Fault Complex at some point in the Early Cretaceous became incorporated into the rotated hanging wall of a continent-facing half-graben bound in the northwest by the FFC. In this scenario, the extremely deep and poorly imaged Rås Basin did not entirely develop as a thermally controlled basin. We suggest that it started out as a supradetachment basin, but that is was cut and displaced by the FFC, which turned it into a large, continent-facing, halfgraben basin. Following this phase, the Rås Basin was probably controlled by thermal subsidence, disturbed only by reactivation of the FFC in the Late Cretaceous and in the Cenozoic. The Ytreholmen Fault zone would, correspondingly, change its role from that of a major detachment to a flexed and onlapped hanging wall flank.

Interpretations of unroofed detachment faults and likely windows of exhumed mantle in the outer parts of the margin invites the question as to why the outer ridges system (Rån Ridge, South and North Gjallar Ridges) as well as the northwestern parts of the Møre Basin occupied structurally high positions in much of the Cretaceous. Stratigraphic evidence for this is provided by onlap relationships on the southeastern flanks of the Ran and Gjallar Ridges as well as a pinchout of upper parts of the Cretaceous succession along the northern Møre margin. Removal of significant parts of or the entire crustal section in the outer margin in Cretaceous time can be regarded as contradicting Cretaceous uplift of these areas. However, in areas of strong crustal thinning, serpentinisation of mantle would lead to volume increase and density decrease, and thus potentially to further uplift. Another possible solution may lie in the magmatic evolution of the margin system prior to breakup. Intrusions and volcanic rocks that were interpreted and sampled on the Norwegian margin have been assigned to Early Cenozoic ages (e.g., Svensen et al., 2010). However, if Cretaceous extension proceeded as far as suggested by some of the above scenarios, it cannot be excluded that magmatic products were stored under the outer margin from Cretaceous time onwards, perhaps during formation of the distal or outer detachments described above, without reaching the surface. The thermal effect associated with a raised asthenosphere due to lithosphere thinning and to emplacement of magmatic rocks at depth would cause regional uplift, even of areas with exhumed mantle on the outer margin (e.g., Bronner et al., 2011). Thus, the above scenarios with strongly thinned crust and/or exhumed mantle in the outer margin are not necessarily in contradiction to a structurally elevated position of the outer margin in the Cretaceous.

\section{Conclusions}

- The successive incision of deep, continent-dipping reflectors over tens of kilometres in areas of already hyperextended crust indicates unroofing of mantle rocks in the footwalls of major detachments in the deep margin offshore Norway.

- One of the best imaged examples of an 'exhumationtype' detachment offshore Norway so far is in the Vøring Basin, at the trailing edge of the Rån Ridge. We suspect that parts of this major detachment were linked to the Ytreholmen Fault zone, with flat-lying detachments west of the Slettringen Ridge and perhaps with a proposed northwest-rising detachment in the northeast Møre Basin.

- A younger detachment was active northwest of Rån and in the area that developed into the Gjallar Ridge. The hanging wall of this detachment contains pervasively faulted Cretaceous strata to great depth.

- Interpretations of strongly thinned crust or exhumed mantle in areas that were structurally high in the Cretaceous may be justified by volume increase and density decrease related to serpentinisation and by thermal response to extreme crustal thinning and mantle hydration.

- The landward-dipping Fles Fault Complex cut and displaced the above system of successively incising detachments. The Rås Basin, originally formed on seaward-dipping detachment fault(s), changed to a continent-facing half-graben before abandonment and thermal relaxation. Parts of the FFC were reactivated with reverse displacements in the Cenozoic.

- Ambiguity related to overlapping densities and velocities of different basement lithologies does, however, hamper a unique solution of the deep-seated lithological and structural architecture and thus the details of the tectonic model. 
Acknowledgements. We thank Erik Lundin and Geoffroy Mohn for their insightful reviews. We thank ExxonMobil for financial support to the CONTEC project and for permission to publish project results. We are grateful to TGS NOPEC and Spectrum for permission to publish selected parts of the MNR seismic reflection survey and for access to nonreleased seismic data for temporary interpretation purposes. We thank Schlumberger asa for the use of their interpretation software $\left(\right.$ Petrel $\left.^{(R)}\right)$ and Franlab-Beicip for the use of their seismic interpretation and depth conversion module Easydepth ${ }^{(\mathrm{R})}$

\section{References}

Berndt, C., Planke, S., Alvestad, E., Tsikalas, F. \& Rasmussen, T. 2001: Seismic volcanostratigraphy of the Norwegian margin: constraints on tectonomagmatic break-up processes. Journal of the Geological Society of London 158, 413-426. https://doi.org/10.1144/jgs.158.3.413.

Blaich, O.A., Faleide, J.I., Tsikalas, F., Lilletveit, R., Chiossl, D., Brockbank, P. \& Cobbold, P. 2010: Structural architecture and nature of the continent-ocean transitional domain at the Camamu and Almada basins (NE Brazil) within a conjugate margin setting. In Vining, B.A. \& Pickering, S.C. (eds.): Petroleum Geology: from Mature Basins to New Frontiers - Proceedings of the 7th Petroleum Geology Conference, Geological Society of London, pp. 867-883. https://doi.org/10.1144/0070867.

Blaich, O.A., Faleide, J.I \& Tsikalas, F. 2011: Crustal breakup and continent-ocean transition at South Atlantic conjugate margins. Journal of Geophysical Research 116, 38 pp. https://doi.org/10.1029/2010JB007686.

Blystad, P., Brekke, H., Færseth, R.B., Larsen, B.T., Skogseid, J. \& Tørudbakken, B. 1995: Structural elements of the Norwegian continental shelf, Part II: The Norwegian Sea Region. Norwegian Petroleum Directorate Bulletin 8, 0-45.

Boillot, G., Grimaud, S., Mauffret, A., Mougenot, D., Kornprobst, J., Mergoil-Daniel, J. \& Torrent, G. 1980: Ocean-continent boundary off the Iberian margin: a serpentinite diapir west of the Galicia Bank. Earth and Planetary Science Letters 48, 23-34. https://doi.org/10.1016/0012-821X(80)90166-1.

Breivik, A.J., Mjelde, R., Raum, T., Faleide, J.I., Murai, Y. \& Flueh, E.R. 2011: Crustal structure beneath the Trøndelag Platform and adjacent areas of the mid-Norwegian margin, as derived from wideangle seismic and potential field data. Norwegian Journal of Geology 90, 141-161.

Brekke, H. 2000: The tectonic evolution of the Norwegian Sea Continental Margin with emphasis on the Vøring and Møre Basins. In Nøttvedt, A. (ed.): Dynamics of the Norwegian Margin, Geological Society Special Publication 167, Geological Society of London, pp. 327-378. https://doi.org/10.1144/gsl.sp.2000.167.01.13.

Bronner, A., Sauter, D., Manatschal, G., Péron-Pinvidic, G. \& Munschy, M. 2011: Magmatic breakup as an explanation for magnetic anomalies at magma-poor rifted margins. Nature Geoscience 4, 549-553. https://doi.org/10.1038/ngeo1201.

Bugge, T., Ringås, J.E., Leith, D.A., Mangerud, G., Weiss, H.M. \& Leith, T.L. 2002: Upper Permian as a new play model on the mid-Norwegian continental shelf: Investigated by shallow stratigraphic drilling. American Association of Petroleum Geologists Bulletin 86, 107-127.

Dean, S.M., Minshull, T.A., Whitmarsh, R.B. \& Louden, K.E. 2000: Deep structure of the ocean-continent transition in the southern Iberia Abyssal Plain from seismic refraction profiles: The IAM-9 transect at 40020' N. Journal of Geophysical Research 105, 58595885. https://doi.org/10.1029/1999JB900301.

Dietze, F. \& Kontny, A. 2011: A study of rock magnetic properties of serpentinites from the Outokumpu deep drillhole, Finland. In Kukkonen, I.T. (ed.): Outokumpu Deep Drilling Project 2003-2010, Geological Survey of Finland Special Paper 51, pp. 133-150.
Doré, A.G., Lundin, E.R., Jensen, L.N., Birkeland, Ø., Eliassen, P.E. \& Fichler, C. 1999: Principal tectonic events in the evolution of the northwest Atlantic margin. In Fleet, A.J. \& Boldy, A.A.R. (eds.): Petroleum Geology of Northwest Europe - Proceedings of the 5th Conference, Geological Society of London, pp. 41-61. https://doi.org/10.1144/0050041.

Ebbing, J. \& Olesen, O. 2010: New compilation of top basement and basement thickness for the Norwegian continental shelf reveals the segmentation of the passive margin system. Geological Society of London, Petroleum Geology Conference series 7, 885-897.

Ebbing, J., Lundin, E.R., Olesen, O. \& Hansen, E.K. 2006: The midNorwegian margin: a discussion of crustal lineaments, mafic intrusions, and remnants of the Caledonian root by 3D density modelling and structural interpretation. Journal of the Geological Society of London 163, 47-59. https://doi.org/10.1144/0016-764905-029.

Ebbing, J., Gernigon, G., Pascal, C., Olesen, O. \& Osmundsen, P.T. 2009: A discussion of structural and thermal control of magnetic anomalies on the mid-Norwegian margin. Geophysical Prospecting 57, 665-681. https://doi.org/10.1111/j.1365-2478.2009.00800.x.

Ehrlich, R. \& Gabrielsen, R.H. 2004: The complexity of a ramp-flat fault and its effect on hanging-wall structuring: an example from the Njord oil field, offshore Mid Norway. Petroleum Geoscience 10, 305-317. https://doi.org/10.1144/1354-079303-585.

Faleide, J.I., Tsikalas, F., Breivik, A.J., Mjelde, R., Ritzmann, O., Engen, Ø., Wilson, J. \& Eldholm, O. 2008: Structure and evolution of the continental margin off Norway and the Barents Sea. Episodes 31, 82-91.

Fjellanger, E., Surlyk, F., Wamsteeker, L.C. \& Midtun, T. 2005: Upper Cretaceous basin-floor fans in the Vøring Basin, Mid Norway shelf. In Wandås, B., Nystuen, J.P., Eide, E. \& Gradstein, F.M. (eds.): Onshore-Offshore Relationships on the North Atlantic Margin, Norwegian Petroleum Society Special Publications 12, pp. 135-164.

Franke, D. 2012: Rifting, lithosphere breakup and volcanism: Comparison of magma-poor and volcanic rifted margins. Marine and Petroleum Geology 43, 63-87. https://doi.org/10.1016/j.marpetgeo.2012.11.003.

Gernigon, L., Ringenbach, J.-C., Planke, S. \& Le Gall, B. 2004: Deep structures and breakup along volcanic rifted margins: insights from integrated studies aling the outer Vøring Basin (Norway). Marine and Petroleum Geology 21, 363-372. https://doi.org/10.1016/j.marpetgeo.2004.01.005.

Götze, H.-J. \& Lahmeyer, B. 1988: Application of three-dimensional interactive modeling in gravity and magnetics. Geophysics 53, 1096-1108. https://doi.org/10.1190/1.1442546.

Guillot, S., Schwartz, S., Reynard, B., Agard, P. \& Prigent, C. 2015: Tectonic significance of serpentinites. Tectonophysics 646, 1-19. https://doi.org/10.1016/j.tecto.2015.01.020.

Jongepier, K., Rui, J.C. \& Grue, K. 1996: Triassic to Early Cretaceous stratigraphic and structural development of the northeastern Møre Basin margin, off Mid-Norway. Norsk Geologisk Tidsskrift 76, 199214.

Kvarven, T., Ebbing, J., Mjelde, R., Faleide, J.I., Libak, A., Thybo, H., Flueh, E.R. \& Murai, Y. 2014: Crustal structure across the Møre margin, mid-Norway, from wide-angle seismic and gravity data. Tectonophysics 626, 21-40. https://doi.org/10.1016/j.tecto.2014.03.021.

Lundin, E.R. \& Doré, A.G. 1997: A tectonic model for the Norwegian passive margin with implications for the NE Atlantic: Early Cretaceous to break-up. Journal of the Geological Society of London 154, 545-550. https://doi.org/10.1144/gsigs.154.3.0545.

Lundin, E.R. \& Doré, A.G. 2011: Hyperextension, serpentinization, and weakening: A new paradigm for rifted margin compressional deformation. Geology 39, 347-350. https://doi.org/10.1130/G31499.1.

Manatschal, G. 2004: New models for evolution of magma-poor rifted margins based on a review of data and concepts from West Iberia and the Alps. International Journal of Earth Sciences 93, 432-466. https://doi.org/10.1007/s00531-004-0394-7. 
Manatschal, G., Froitzheim, N., Rubenach, M. \& Turrin, B.D. 2001: The role of detachment faulting in the formation of an ocean-continent transition: insights from the IberiaAbyssal Plain. In Wilson, R.C.L., Whitmarsh, R.B., Taylor, B. \& Froitzheim, N. (eds.): Non-Volcanic Rifting of Continental Margins: A Comparison of Evidence from Land and Sea, Geological Society of London Special Publication 187, pp. 405-428. https://doi.org/10.1144/gsl.sp.2001.187.01.20.

Manatschal, G., Müntener, O., Lavier, L.L., Minshull, T.A. \& PéronPinvidic, G. 2007: Observations from the Alpine Tethys and IberiaNewfoundland margins pertinent to the interpretation of continental breakup. In Karner, G.D., Manatschal, G. \& Pinheiro, L.M. (eds.): Imaging, Mapping and Modelling Continental Lithosphere Extension and Breakup, Geological Society of London Special Publications 282, pp. 291-324. https://doi.org/10.1144/sp282.14.

Marsh, N., Imber, J., Holdsworth, R.E., Brockbank, P. \& Ringrose, P. 2010: The structural evolution of the Halten Terrace, offshore Mid-Norway: extensional fault growth and strain localization in a multi-layer brittle-ductile system. Basin Research 22, 195-214. https://doi.org/10.1111/j.1365-2117.2009.00404.x.

Mjelde, R., Kasahara, J., Shimamura, H., Kamimura, A., Kanazawa, T., Kodaira, S., Raum, T. \& Shiobara, H. 2002: Lower crustal seismic velocity-anomalies; magmatic underplating or serpentinized peridotite? Evidence from the Vøring margin, NE Atlantic. Marine Geophysical Researches 23, 169-183. https://doi.org/10.1023/A:1022480304527.

Mjelde, R., Raum, T., Breivik, A., Shimamura, H., Murai, Y., Takanami, T. \& Faaleide, J.I. 2005: Crustal structure of the Vøring Margin, NE Atlantic: a review of geological implications based on recent OBS data. In Doré, A.G. \& Vining, B.A. (eds.): Petroleum Geology: North-west Europe and Gobal Perspectives - Proceedings of the 6th Petroleum Geology Conference, Geological Society of London, pp. 803-813.

Mjelde, R., Raum, T., Kandilarov, A., Murai, Y. \& Takanami, T. 2009a: Crustal structure and evolution of the outer Møre margin, NE Atlantic. Tectonophysics 468, 224-243. https://doi.org/10.1016/j.tecto.2008.06.003.

Mjelde, R., Faleide, J.I., Breivik, A.J. \& Raum, T. 2009b: Lower crustal composition and crustal lineaments on the Vøring Margin, NE Atlantic: A review. Tectonophysics 472, 183-193.

https://doi.org/10.1016/j.tecto.2008.04.018.

Mjelde, R., Goncharov, A. \& Müller, R.D. 2012: The Moho: Boundary above upper mantle peridotites or lower crustal eclogites? A global review and new interpretations for passive margins. Tectonophysics 609, 636-650. https://doi.org/10.1016/j.tecto.2012.03.001.

Müller, R., Nystuen, J.P., Eide, F. \& Lie, H. 2005: Late Permian to Triassic basin infill history and palaeogeography of the Mid-Norwegian shelf-East Greenland region. In Wandås, B., Nystuen, J.P., Eide, E. \& Gradstein, F.M. (eds.): Onshore-Offshore relationships on the North Atlantic Margin, Norwegian Petroleum Society Special Publications 12, pp. 165-189. https://doi.org/10.1016/s0928-8937(05)80048-7.

Nirrengarten, M., Gernigon, L. \& Manatschal, G. 2014: Lower crustal bodies in the Møre volcanic rifted margin: Geophysical determination and geological implications. Tectonophysics 636, 143-157. https://doi.org/10.1016/j.tecto.2014.08.004.

Olesen, O., Brönner, M., Ebbing, J., Gellein, J., Genrigon, L., Koziel, J., Lauritsen, T., Myklebust, R., Pascal, C., Sand, M., Solheim, D. \& Usov, S. 2010a: New aeromagnetic and gravity compilations from Norway and adjacent areas: methods and applications. Geological Society of London, Petroleum Geology Conference series 7, 559-586.

Olesen, O., Ebbing, J., Gellein, J., Kihle, O., Myklebust, R., Sand, M., Skilbrei, J.R., Solheim, D. \& Usov, S. 2010b: Gravity anomaly map, Norway and adjacent areas, scale 1:3,000,000, Norges geologiske undersøkelse.

Osmundsen, P.T. \& Ebbing, J. 2008: Styles of extension offshore midNorway and implications for mechanisms of crustal thinning at passive margins. Tectonics 27, 1-25.

https://doi.org/10.1029/2007TC002242.
Osmundsen, P.T. \& Redfield, T. 2011: Crustal taper and topography at passive continental margins. Terra Nova 23, 349-361. https://doi.org/10.1111/j.1365-3121.2011.01014.x.

Osmundsen, P.T., Sommaruga, A., Skilbrei, J.R. \& Olesen, O. 2002: Deep structure of the Mid Norway rifted margin. Norwegian Journal of Geology 82, 205-224.

Oufi, O., Cannat, M. \& Horen, H. 2002: Magnetic properties of variably serpentinized abyssal peridotites. Journal of Geopysical Research 107, EPM 3-1-EPM 3-19. https://doi.org/10.1029/2001JB000549.

Pérez-Gussinyé, M. \& Reston, T.J. 2001: Rheological evolution during extension at passive non-volcanic margins: onset of serpentinization and development of detachments to continental break-up. Journal of Geophysical Research 106, 3691-3975. https://doi.org/10.1029/2000JB900325.

Péron-Pinvidic, G. \& Manatschal, G. 2009: The final rifting evolution at deep magma-poor passive margins from Iberia-Newfoundland: a new point of view. International Journal of Earth Sciences (Geologisches Rundschau) 98, 1581-1597. https://doi.org/10.1007/s00531-008-0337-9.

Péron-Pinvidic, G. \& Osmundsen, P.T. 2016: Architecture of the distal and outer domains of the Mid-Norwegian margin: insights from the Rån Ridge. Marine and Petroleum Geology 77, 280-299. https://doi.org/10.1016/j.marpetgeo.2016.06.014.

Péron-Pinvidic, G., Manatschal, G., Minshull, T. \& Sawyer, D.S. 2007: Tectonosedimentary evolution of the deep Iberia-Newfoundland margins: Evidence for a complex breakup history. Tectonics 26, 1-19. https://doi.org/10.1029/2006TC001970.

Péron-Pinvidic, G., Gernigon, L., Gaina, C. \& Ball, P. 2012: Insights from the Jan Mayen system in the Norwegian-greenland Sea-II. Architecture of a microcontinent. Geophysical Journal International 191,413-435. https://doi.org/10.1111/j.1365-246X.2012.05623.x.

Péron-Pinvidic, G., Manatschal, G. \& Osmundsen, P.T. 2013: Structural comparison of archetypal Atlantic rifted margins: A review of observations and concepts. Marine and Petroleum Geology 43, 21-47. https://doi.org/10.1016/j.marpetgeo.2013.02.002.

Péron-Pinvidic, G., Osmundsen, P.T. \& Ebbing, J. 2016: Mismatch of geophysical datasets in distal rifted margin studies. Terra Nova 28, 340-347. https://doi.org/10.1111/ter.12226.

Planke, S., Symonds, P.A., Alvestad, E. \& Skogseid, J. 2000: Seismic volcanostratigraphy of large-volume basaltic extrusive complexes on rifted margins. Journal of Geophysical Research: Solid Earth 105, 19335-19351. https://doi.org/10.1029/1999JB900005.

Planke, S., Rasmussen, T., Rey, S.S. \& Myklebust, R. 2005: Seismic characteristics and distribution of volcanic intrusions and hydrothermal vent complexes in the Vøring and Møre basins. Geological Society of London, Petroleum Geology Conference series 6, pp. 833844.

Ranero, C.R. \& Pérez-Gussinyé, M. 2010: Sequential faulting explains the asymmetry and extension discrepancy of conjugate margins. Nature 468, 294-299. https://doi.org/10.1038/nature09520.

Raum, T., Mjelde, R., Digranes, P., Shimamura, H., Kodaira, S., Haatvedt, G., Sørenes, N. \& Thorbjørnsen, T. 2002: Crustal structure of the southern part of the Vøring Basin, Mid-Norway margin, from wide-angle seismic and gravity data. Tectonophysics 355, 99-126. https://doi.org/10.1016/S0040-1951(02)00136-1.

Ren, S., Skogseid, J. \& Eldholm, O. 1998: Late Cretaceous-Paleocene extension on the Vøring Volcanic margin. Marine Geophysical Researches 20,343-369. https://doi.org/10.1023/A:1004554217069.

Reston, T.J. 1996: The S reflector west of Galicia: The seismic signature of a detachment fault. Geophysical Journal International 127, 230-244. https://doi.org/10.1111/j.1365-246X.1996.tb01547.x.

Reston, T.J. 2009: The structure, evolution and symmetry of the magma-poor rifted margins of the North and Central Atlantic: A synthesis. Tectonophysics 468, 6-27.

https://doi.org/10.1016/j.tecto.2008.09.002. 
Reston, T.J., Pennell, J., Stubbenrauch, A., Walker, I. \& Pérez-Gussinyé, M. 2001: Detachment faulting, mantle serpentinization, and serpentinite-mud volcanism beneath the Porcupine Basin, southwest of Ireland. Geology 29, 587-590.

https://doi.org/10.1130/0091-7613(2001)029<0587:DFMSAS>2.0.CO;2.

Reynard, B., Nakajima, J. \& Kawakatsu, H. 2010: Earthquakes and plastic deformation of anhydrous slab mantle in double Wadati-Benioff zones. Geopysical Research Letters 37, L24309. https://doi.org/10.1029/2010GL045494.

Reynisson, F., Ebbing, J., Lundin, E. \& Osmundsen, P.T. 2011: Properties and distribution of lower crustal bodies on the midNorwegian margin. In Vining, B.A. \& Pickering, S.C. (eds.): Petroleum Geology: from Mature Basins to New Frontiers Proceedings of the 7th Petroleum Geology conference, pp. 843-854. https://doi.org/10.1144/0070843.

Rüpke, L.H., Schmid, D., Pérez-Gussinyé, M. \& Hartz, E. 2013: Interrelation between rifting, faulting, sedimentation and mantle serpentinization during continental marginformation - including examples from the Norwegian Sea. Geochemistry, Geophysics, Geosystems 14,4351-4369. https://doi.org/10.1002/ggge.20268.

Savva, D., Pubellier, M., Franke, D., Chamot-Rooke, N., Meresse, F., Steuer, S. \& Auxietre, J.L. 2014: Different expressions of rifting on the South China Sea margins. Marine and Petroleum Geology 58, 579-598. http://dx.doi.org/10.1016/j.marpetgeo.2014.05.023.

Shipboard Scientific Party 1987a: Site 639. In Boillot, G., Winterer, E.L. Meyer, A.W. et al. (eds.): Proceedings of the Ocean drilling Program, Initial Reports 173, Ocean Drilling Program, College Station, TX, pp. 409-532.

Shipboard Scientific Party 1987b: Site 641. In Boillot, G., Winterer, E.L., Meyer, A.W. et al. (eds.): Proceedings of the Ocean drilling Program, Initial Reports 173, Ocean Drilling Program, College Station, TX, pp. 571-660.

Shipboard Scientific Party 1994: Site 897. In Sawyer, D.S., Whitmarsh, R.B., Klaus, R.B. \& Shipboard Scientific Party (eds.): Proceedings of the Ocean Drilling Program, Initial Reports 149, Ocean Drilling Program, College Station, TX, pp. 41-113.

Shipboard Scientific Party 2004: Leg 210 summary. In Tucholke, B.E., Sibuet, J.-C., Klaus, A. et al. (eds.): Proceedings for the Ocean Drilling Program, Initial Reports 210, Ocean Drilling Program, College Station, TX, pp. 1-78

Skogseid, J., Pedersen, T., Eldholm, O. \& Larsen, B.T. 1992: Tectonism and magmatism during NE Atlantic continental break-up: the Vøring margin. In Storey, B.C., Alabaster, T. \& Pankhurst, R.J. (eds.): Magmatism and the causes of continental break-up, Geological Society of London Special Publications 68, pp. 305-320. https://doi.org/10.1144/gsl.sp.1992.068.01.19.

Souche, A., Beyssac, O. \& Andersen, T.B. 2012: Thermal structure of supradetachment basins: a case study of the Devonian basins of western Norway. Journal of the Geological Society of London 169, 427-434. https://doi.org/10.1144/0016-76492011-155.

Stica, J., Zalán, P.V. \& Ferrari, A.L. 2014: The evolution of rifting on the volcanic margin of the Pelotas Basin and the conceptualization of the Paraná-Etendeka LIP in the separation of Gondwana in the South Atlantic. Marine and Petroleum Geology 50, 1-21. https://doi.org/10.1016/j.marpetgeo.2013.10.015.

Sutra, E., Manatschal, G., Mohn, G. \& Unternehr, P. 2013: Quantification and restoration of extensional deformation along the Western Iberia and Newfoundland rifted margins. Geochemistry, Geophysics, Geosystems 14, 2575-2597. https://doi.org/10.1002/ggge.20135.

Svensen, H., Planke, S. \& Corfu, F. 2010: Zircon dating ties NE Atlantic sill emplacement to initial Eocene global warming. Journal of the Geological Society of London 167, 433-436. https://doi.org/10.1144/0016-76492009-125.

Swiecicki, T., Gibbs, P.G., Farrow, G.E. \& Coward, M.P. 1998: A tectonostratigraphic framework for the Mid-Norway region. Marine and Petroleum Geology 15, 245-258. https://doi.org/10.1016/S0264-8172(97)00029-9.
Torske, T. \& Prestvik, T. 1991: Mesozoic detachment faulting between Greenland and Norway: Inferences from Jan Mayen Fracture Zone system and associated alcalic volcanic rocks. Geology 19, 481-484. https://doi.org/10.1130/0091-7613(1991)019<0481:MDFBGA>2.3.CO;2.

Tugend, J., Manatschal, G., Kusznir, N.J., Masini, E., Mohn, G. \& Thinon, I. 2014: Formation and deformation of hyperextended rift systems: Insights from rift domain mapping in the Bay of Biscay-Pyrenees. Tectonics 33, 1239-1276. https://doi.org/10.1002/2014TC003529.

Whitmarsh, R.B., Minshull, T.A., Russell, S.M., Dean, S.M., Louden, K.E. \& Chian, D. 2001: The role of syn-rift magmatism in the rift-todrift evolution of the West Iberia continental margin: geophysical observations. In Wilson, R.C.L., Whitmarsh, R.B., Taylor, B. \& Froitzheim, N. (eds.): Non-Volcanic Rifting of Continental Margins: A Comparison of Evidence from Land and Sea, Geological Society of London Special Publications 187, pp. 107-124. https://doi.org/10.1144/gsl.sp.2001.187.01.06. 